\title{
THE BROADCAST LICENSEE AS FIDUCIARY: TOWARD THE ENFORCEIVENT OF DISCRETION
}

\author{
JoNATHAN MALLAMUD*
}

Under the traditional view of the first amendment to the United States Constitution, the protection of freedom of speech requires that the government abstain from engaging in any activity affecting speech unless that activity is essential to the protection of some other vital governmental interest. ${ }^{1}$ But recent arguments for a right of access to the broadcast media proceed upon the basis that this traditional theory of the first amendment is madequate because it fails to ensure a sufficiently vital marketplace for the full expression of ideas that is necessary in our democratic state. ${ }^{2}$ At the same time,

* Associate Professor, Rutgers University School of Law-Camden. A.B. 1958, Oberlin College; J.D. 1961, Harvard University.

1. See, e.g., New York Times Co. v. Sullivan, 376 U.S. 254 (1964); Roth v. United States, 354 U.S. 476, 488 (1957); Thomas v. Collins, 323 U.S. 516 (1945). THE FOLLOWING HEREINAFTER CITATIONS ARE USED IN THIS ARTICLE:

Barron, An Emerging First Amendment Right of Access to the Media?, 37 Geo. Wash. L. Rev. 487 (1969) [hereinafter cited as Barron, An Emerging First Amendment Right];

Barron, Access to the Press-A New First Amendment Right, 80 HARv. L. Rev. 1641 (1967) [hereinafter cited as Barron, Access to the Press];

Barrow, The Equal Opportunities and Fairness Doctrine in Broadcasting: Pillars in the Forum of Democracy, 37 U. CIN. L. Rev. 447 (1968) [hereinafter cited as Barrow];

Jaffe, The Editorial Responsibility of the Broadcaster: Reflections on Fairness and Access, 85 HARV. L. REv. 768 (1972) [hereinafter cited as Jaffe];

Johnson \& Westen, A Twentieth-Century Soapbox: The Right to Purchase Radio and Television Time, 57 VA. L. REv. 574 (1971) [heremafter cited as Jolunson $\&$ Westen];

Kalven, Broadcasting, Public Policy and the First Amendment, 10 J. LAw \& EcoN. 15 (1967) [hereinafter cited as Kalven];

Loevinger, Free Speech, Faimess, and Fiduciary Duty in Broadcasting, 34 LAw \& CONTEMP. ProB. 278 (1969) [hereinafter cited as Loevinger];

Malone, Broadcasting, the Reluctant Dragon: Will the First Amendment Right of Access End the Suppressing of Controversial Ideas?, 5 J. OF LAW REFoRM 194 (1972) [hereinafter cited as Malone];

Marks, Broadcasting and Censorship: First Amendment Theory After Red Lion, 38 GeO. WASH. L. REv. 974 (1970) [hereinafter cited as Marks].

2. See Barron, An Emerging First Amendment Right 499-509; Jolinson \& Westen 603-04; cf. Barron, Access to the Press 1642-43. See also Horning, The First Amendment Right to a Public Forum, 1969 DUke L.J. 931, 954; Mayo, The 


\section{the Federal Communication Commission's (FCC) fairness doctrine, ${ }^{3}$}

Free Forum: Development of a Democratic Forum in the Limited Media of Mass Communication, 22 Geo. Wash. L. REv. 387 (1954). For a recent and comprehensive discussion of the right of access, see Malone.

3. The FCC's fairness doctrine requires that broadcast licensees give fair coverage to each side of public issues. The doctrine was first set out in detail in Editorializing by Broadcast Licensees, 13 F.C.C. 1246 (1949); however, the FCC had mentioned the concept of fairness earlier. See United Broadcasting Co., 10 F.C.C. 515, 517 (1945). The FCC further explained the doctrine in Applicability of the Fairness Doctrine in the Handling of Controversial Issues of Public Importance, 40 F.C.C. 598 (1964), and the Supreine Court has summarized it concisely (including the personal attack rules) in Red Lion Broadcasting Co. v. FCC, 395 U.S. 367, 369-70, 373-79 (1969). The doctrine was given congressional recognition when section 315 of the Communications Act of 1934, 47 U.S.C. \& 315 (1970), was amended in 1959. Act of Sept. 14, 1959, Public Law 86-274, 73 Stat. 557. Following the Supreme Court decision in Red Lion, the FCC issued a Notice of Inquiry and a Notice of Proposed Rulemaking to reconsider the fairness doctrine and possibly to clarify it. Obligations of Broadcast Licensees Under the Fairness Doctrine, 23 F.C.C.2d 27 (1970). Even before Red Lion, the fairness doctrine had been extended to cigarette advertising. Banzhaf v. FCC, 405 F.2d 1082 (D.C. Cir. 1968), cert. denied, 396 U.S. 842 (1969). Thereafter, it became apparent that the fairness doctrine could be extended to other kinds of advertising. See Friends of the Earth v. FCC, 449 F.2d 1164 (D.C. Cir. 1971). But see Green v. FCC, 447 F.2d 323 (D.C. Cir. 1971); Neckritz v. FCC, 446 F.2d 501 (9th Cir. 1971). After the Friends of the Earth decision, Neckritz was remanded to the FCC, which affirmed its original decision denying the claim that was based on the faimess doctrine. Alan F. Neckritz, 25 P \& F RAdio REg. 2D 631 (1972). Furthermore, the right of access also received judicial recognition. Business Executives' Move for Vietnam Peace v. FCC, 450 F.2d 642 (D.C. Cir. 1971), cert. granted, 405 U.S. 953 (1972) (argued on October 16, 1972, see 41 U.S.L.W. 3224 (1972) ); Retail Store Employees Union, Local 880 v. FCC, 436 F.2d 248 (D.C. Cir. 1970). In order to reconsider the fairness doctrine, the right of access, and the application of the fairness doctrine to political broadcasting, the FCC instituted, by Notice of Inquiry, a proceeding entitled The Handling of Public Issues Under the Fairness Doctrine and the Public Interest Standards of the Communications Act. See 30 F.C.C.2d 26 (1971). Following the grant of certiorari by the Supreme Court in FCC v. Business Executives' Move for Vietnam Peace, the FCC indicated that a final decision by the FCC on the right of access would have to await the Supreme Court's decision in that case. See Order and Further Notice of Inquiry, The Handling of Public Issues Under the Fairness Doctrine and the Public Interest Standards of the Communications Act, P \& F RADIO REG. (1972 Current Service) 53:463. In June 1972, the FCC issued its first report, Handling of Political Broadcasts. See 24 P \& F RADro Reg. 2D 1917 (1972). Thus, at this time both the FCC's fairness doctrine and the right of access must be considered in a somewhat less than stable state. The complexity and sensitivity of the problems presented are illustrated by the disputes that arise under the fairness doctrine by each of the two major political parties seeking reply time to political broadcasts, see, e.g., Democratic Nat'l Comm. v. FCC, 460 F.2d 891 (D.C. Cir. 1972), cert. denied, 41 U.S.L.W. 3184 (U.S. Oct. 3, 1972), and the subject of counteradvertising. See Note, Television Counteradvertising: "And Now a Word Against Our Sponsor. . ..," 3 RUTGers CAMden L.J. 516 (1972). 
which purports to assure balanced coverage of controversial issues on radio and television, received its constitutional support from the first amendment's purpose "to preserve an uninhibited marketplace of ideas in which truth will ultimately prevail."4

As early as 1947 Professor Zechariah Chafee, Jr., wrote:

The mere absence of governmental restrictions will not make newspapers and other instrumentalities of communication play their proper part in the kind of society we desire. In addition, affirmative action must be taken either by the government or by other persons with power to influence methods and content. 5

As the justification for the fairness doctrine, the FCC pointed out that mass communications should serve to further the "development of an informed public opinion through the public dissemination of

The main difference between the fairness doctrine and the right of access is that under the fairness doctrine a party challenging a station's presentation on the grounds of fairness need not be given a right to reply, but the fairness obligation is met by the licensee complying with the fair coverage requirement in a manner decided by the licensee. See Democratic Nat'l Comm. v. FCC, 460 F.2d 891, 902-03 (D.C. Cir. 1972). Access requires that a person be given the opportunity to present views directly over the facilities of a licensee. See note 11 infra and accompanying text. See also Johnson \& Westen 579, 606. Cf. Barron, Access to the Press 1667. Under the fairness doctrine the only requirements that specific people be given a right to reply deal with cases of personal attacks or editorials taking sides among competing candidates. See Handling of Public Issues Under the Fairness Doctrine and the Public Interest Standards of the Commumications Act, 30 F.C.C.2d 26, 28 (1971); 47 C.F.R. $\S \S 73.123, .300, .598, .679$ (1972) (all identical).

A great deal has been written about the right of access and the fairness doctrine, and, consequently, there is no need to discuss the history or details of those doctrines here. For the history and details of the right of access and the faimess doctrine, see, e.g., Barron, In Defense of "Fairness": A First Amendment Rationale for Broadcasting's Fairness Doctrine, 37 U. Colo. L. Rev. 31 (1964); Barron, The Federal Communications Commission's Fairness Doctrine, 30 GEo. WasH. L. REv. 1 (1961); Barrow; Blake, Red Lion Broadcasting Co. v. FCC: Fairness and the Emperor's New Clothes, 23 FED. CoM. B.J. 75 (1969); Houser, The Fairness Doctrine-An Historical Perspective, 47 NOTRE DAME LAwyer 550 (1972); Johnson \& Westen; Loevinger; Malone; Marks; Robinson, The FCC and the First Amendment: Observations on 40 Years of Radio and Television Regulation, 52 MINN. L. REv. 67, 127-51 (1967); Sullivan, Editorials and Controversy: The Broadcaster's Dilemma, 32 Geo. Wash. L. REv. 719 (1964); Note, A Fair Break for Controversial Speakers: Limitations of the Fairness Doctrine and the Need for Individual Access, 39 GEo. Wash. L. REv. 532 (1971); Note, From the F.C.C.'s Faimess Doctrine to Red Lion's Fiduciary Principle, 5 HaRv. Civ. Rights-Civ. Lib. L. Rev. 89 (1970); Note, Fairness Doctrine: Television as a Marketplace of Ideas, 45 N.Y.U.L. REv. 1222 (1970).

4. Red Lion Broadcasting Co. v. FCC, 395 U.S. 367, 390 (1969).

5. 2 Z. Chafee, Jr., Government and Mass Communications 471 (1947). See also 1 id. at 28; Mayo, supra note 2, at 391, 391 n.8. 
news and ideas concerning the vital public issues of the day." But for the fairness doctrine to succeed, the FCC, a governinent agency, must involve itself to some extent in the evaluation of the content of broadcast programming. ${ }^{7}$ Thus, on the one hand, to the extent that control of the mass communications media is im private hands, the general public's right to free speech is severely limited. ${ }^{8}$ On the other hand, any attempt to promote free speech by regulation of content by the FCC raises the issue of governinent infringement upon free speecl1. ${ }^{9}$

To some extent, the problems of government involvement in fairness might be avoided if those who disagreed with the programming presented by a licensee had a right to reply over the facilities of the licensee, or at least had the right to purchase time froin the licensee to state views on controversial subjects of public importance. ${ }^{10}$ The developing concept of a right of access would, if it

6. Editorializing By Broadcast Licensees, 13 F.C.C. 1246, 1249 (1949). See also Red Lion Broadcasting Co. v. FCC, 395 U.S. 367, 390 (1969), where the Supreme Court stated, "[i]t is the right of the public to receive suitable access to social, political, esthetic, moral, and other ideas and experiences whicl is crucial here."

7. Barron, The Federal Communications Commission's Fairness Doctrine, supra note 3, at 24; Marks 1004; Sullivan, supra note 3, at 748, 768. As Professor Harry Kalven wrote,

[t]o a considerable extent the Commission's concern with fairness and with program balance rests on the nonrepreseutative nature of broadcasting today. And since these concerns run against the economic self-interest of the broadcaster they are doomed to futility unless the FCC is forced to play a role of so directly controlling programming as to conflict flagrantly with the First Amendmeut. Kalven 32.

A footnote to the title of Kalven's article reads as follows:

This essay is largely based on a memorandun written a year ago for the Columbia Broadcasting System, a circumstance wlich accounts for certain einphases of style and content. I am most grateful to CBS for their generous support of my study of the broadcasting-free speech problem and for their courtesy in permitting me to borrow so heavily from the memorandum here. Id. at 1 n.1.

See also Blake, supra note 3, at 85; Malone 253. Cf. Cronkite, Introduction to Part III: Points of Conflict-Legal Issues Confronting Media Today, 60 Gro. L.J. 1001, 1002 (1972); Ervin, Introduction to Part I: Foundation Media-Evolution of Printed Communication, Media and the First Amendment in a Free Society', 60 GEo. L.J. 871, 872 (1972).

8. See Barron, Access to the Press 1649. The Supreme Court has stated that "the people as a whole retain their interest in free speech by radio and their collective right to have the medium function consistently with the ends and purposes of the First Amendment. It is the right of the viewers and histeners, not the right of the broadcasters, which is paramount." Red Lion Broadcasting Co. v. FCC, 395 U.S. 367, 390 (1969) (citations omitted).

9. See, e.g., Robinson, supra note 3 , at 163 .

10. Democratic Nat'1 Comm., 25 F.C.C.2d 216, 238 (1970) (dissenting opin- 
matured into an enforceable right, permit advocates of positions on public issues to have direct access to a licensee's facilities either to respond to positions taken on those facilities or to discuss issues whicl they select. ${ }^{11}$ Because the licensee would not have editorial control over the content of the controversial material presented, it might appear at first blush that the licensee would not be limiting the free speech of those who might want access. But upon closer analysis, it becomes clear that the licensee would have to decide who will receive access, and that will involve a judgment as to particular issues. Furthermore, the licensee will have to decide llow much time will be allocated for each issue and when the material will be presented. Presumably, the granting of access time will not relieve the licensee of obligations under the fairness doctrine. For these reasons, those dealing with the right of access in broadcasting recognize that the FCC would have to regulate the enforcement of the right. ${ }^{12}$ The problems involved in applying this right of access

ion, Commissioner Nicholas Johnson), rev'd sub nom., Business Executives' Move for Vietnam Peace v. FCC, 450 F.2d 642 (D.C. Cir. 1971), cert. granted, 405 U.S. 953 (1972) (argued on October 16, 1972, see 41 U.S.L.W. 3224 (1972)).

11. See Business Executives' Move for Vietnam Peace v. FCC, 450 F.2d 642, 656 (D.C. Cir. 1971); Malone 254; Note, A Fair Break for Controversial Speakers: Limitations of the Fairness Doctrine and the Need for Individual Access, 39 Geo. WASH. L. REv. 532, 557-58 (1971). In Business Executives' the court of appeals held that a broadcast licensee could not maintain a flat ban on editorial advertising. 450 F.2d at 646,665 . Complainants, charging that a licensee has presented one side of a controversial issue, sometimes request free time to reply to material preseuted on the licensee's facilities. See, e.g., Green v. FCC, 447 F.2d 323, 325 (D.C. Cir. 1971). In this context access may be viewed as complementary to the fairness doctrine, although to the extent that it restricts a licensee's discretion it can be argued that access conflicts with the fairness doctrine. See Oral Argument Before the Supreme Court, Business Executives' Move for Vietnam Peace v. FCC, 41 U.S.L.W. 3217-18 (U.S. Oct. 24, 1972). See also Democratic Nat'l Comm., 25 F.C.C.2d 216, 223-26 (1970), rev'd on other grounds sub nom., Business Executives' Move for Vietnain Peace v. FCC, 450 F.2d 642 (D.C. Cir. 1971). The right of access was placed on first amendment grounds in Business Executives. Id. at 646. Because the right of access also can be considered in terms of the public interest, it might even be placed on statutory grounds. Cf. Barron, An Emerging First Amendment Right 498-500. There is also the right of access to the press which is said should follow from the commands of the first amendment. See id. at 488-94; Barron, Access to the Press 1647-56, 1666. At least at first, it appears that such a right would be judicially enforced. See Barron, An Emerging First Amendment Right 495.

12. Business Executives' Move for Vietnam Peace v. FCC, 450 F.2d 642, 664-65 (D.C. Cir. 1971). See Johnson \& Westen 613; Malone 254, 258-61. See also Houser, supra note 3, at 551. Cf. Mayo, The Limited Forum: An Analysis of Restrictions on the Discussion of Public Issues in the Channels of Mass Communication, 22 GEO. WASE. L. REV. 261, 297 (1954). 
can be formidable. After a detailed analysis of one aspect of the right of access problem-access to rebut remarks of the Presidentone writer concludes that it would be better to leave the decisions as to "spokesmen, format, timing and electronic environment" used to answer the President to the "discretion" of broadcast journalists, subject to "the broad standards of 'fairness' and 'reasonableness." "13

Another problem is that even with a working system of access there can be no assurance that those who seek and obtain access will necessarily represent the full spectrum of views necessary to the fair coverage of the issues. And even if they did represent a sufficient cross-section, they may not present their case as effectively as the professional journalist. ${ }^{14}$ The first amendment right that belongs to the people and not the broadcasters ${ }^{15}$ consists of a right to be $\mathrm{m}$ formed, not simply a right to speak. ${ }^{16}$ Therefore, the right of access should not be considered as a substitute for the general obligation of the broadcast kicensee to give fair treatment to important, controversial issues.

What is required is the development and enforcement of a doctrine that would give a broadcast licensee wide discretion concerning the means and details of the presentation of controversial issues of public importance, but, at the same time, prevent a licensee from using that discretion to neglect the coverage of such issues. Although the fairness doctrine sounds as if it would accomplish this, its main

13. Cohn, Access to Television to Rebut the President of the United States: An Analysis and Proposal, 45 TEMP. L.Q. 141, 208 (1972). Cf. Putz, Fairness and Commercial Advertising: A Review and A Proposal, 6 U. SAN Francisco L. Rev. 215,248 (1972). In advocating that a licensee be deemed to have complied with the fairness doctrine insofar as it applies to commercials if he has set aside free reply time, Professor C. Delos Putz, Jr. suggests that although the licensee's discretion should not be reviewed on a case by case basis, the FCC should review it in conjunction with license reuewals every three years. Id.

14. See Malone 267. Although Professor Malone recognizes that reliance on the fairness doctrine is one solution to the problem, he also proposes that lieensees should give professional assistance to those seeking access. Id.

15. Red Lion Broadcasting Co. v. FCC, 395 U.S. 367, 390 (1969).

16. See Meiklejohn, The First Amendment Is An Absolute, 1961 Sup. CT. Rev. 245, 255. See also Note, FCC License Renewal Policy and the Right to Broadcast, 52 Boston U.L. Rev. 94, 134 (1972). Cf. T. Emerson, Toward a General THEORY OF THE FIRST AMENDMENT 10-11 (1966).

The FCC has stated that

the needs and interests of the general public with respect to programs devoted to new [sic] commentary and opinion can only be satisfied by making available to them for their consideration and acceptance or rejection, of varying and conflicting views held by responsible elements of the community. Editorializing by Broadcast Licensees, 13 F.C.C. 1246, 1247 (1949). 
fault appears to be the failure to force licensees to give adequate coverage to controversial issues. ${ }^{17}$ Nevertheless, the thesis presented in this article is that, building on the fairness doctrine, a doctrine can be developed that would enable the FCC to enforce a positive duty of the licensee to use good faith efforts to present controversial issues of public importance. By good faith efforts is ineant a standard that would require coverage of such issues, ${ }^{18}$ and that would prevent licensees from evading their obligation with the claim that the decision on what to present on their station must be left to their discretion. Discretion can be, and really nust be, interpreted to mean discretion as to how to do something, and not discretion to avoid doing it. This point inevitably leads to the question of whether such a doctrine can be enforced so as to insure that the result is not government censorship or government infringement on the full and fair use of the broadcast inedia. ${ }^{19}$ Professor Thomas I. Emerson recognized the need for some government control of the content of radio and television programming and suggested that it is necessary "to formulate reasonably concrete standards, based upon the underlying principle of public service and diversity" and "to develop the institutions and techniques" to apply those standards. ${ }^{20}$ Professor Glen O. Robimson said that "[t]here is no tradition of establishing, for example, standards of 'fairness,' 'diversity,' or 'balance." "21 Former FCC Com-

17. See, e.g., Malone 214-15; Marks 976.

18. It must be recognized that in talking about fair coverage of issues of public importance a great deal more is involved than just news and discussion programs. Issues relevant to the kind of speech protected by the first amendment may be dealt with in a wide range of radio and television programming including what is usually called entertainment programming. See Malone 204-05; Pierson, The Need for Modification of Section 326, 18 FED. COM. B.J. 15, 22 (1963); Note, From the F.C.C.'s Fairness Doctrine, supra note 3. Cf. Meiklejohn, supra note 16, at 256-57, 262.

19. Cf. Kalven 37.

20. EMERSON, supra note 16, at 112.

21. Robinson, supra note 3 , at 161 . Professor Robinson's cominent really indicates that we have been deficient in developing first amendment doctrine. The paragraph froin which the quote in the text is taken reads as follows:

Neither society as a whole, Congress, nor the FCC has ever formulated any principles which satisfactorily guide judginent on such inatters consistent with the aims of an open society. There have developed, in a long Anglo-American tradition of legal and social thinking, various controls on the abuse of free speech, but nowhere in this tradition has there been any developed thinking going beyond sporadic and occasional restraints, such as prohibition of defamatory speech, obscenity, fraud, and otherwise patently harmful or socially disrupting speech. There is no tradition of establishing, for example, standards of "fairness," "diversity," or "balance." These are judgments which, for better or for worse, have been left to the admittedly sometimes quixotic judgment of the public, unguided by their "enlightened" cultural, social, or political leaders. Id. 
missioner Lee Loevinger, on the other hand, found in the fiduciary duty of the licensee, upheld in Red Lion Broadcasting Co. v. FCC, ${ }^{22}$ the beginnings of a doctrine that would permit the FCC to promote the full coverage of views on radio and television without abridging the free speech guaranteed by the first amendment. ${ }^{23}$ Although he admits that the concept of the fiduciary duty might not necessarily "insure a free marketplace of ideas, prevent government censorship, and help maimtain a democratic social and economic order," ${ }^{24}$ lie does not lack some hope for the idea. He concludes:

It never was certain that the principles of the first amendment would be successful. The ideal remains the same. The challenge now is to say what the ideal of free speech means and how it may be achieved in the confused, groping society of today's turbulent technological world. ${ }^{25}$

The present author contends that it is possible to develop the concept of the fiduciary duty of the licensee into a doctrine that will permit the FCC to help establish a marketplace of ideas in broadcasting without permitting the government to inhibit free expression on radio and television. In this article, the author proposes to examine the constitutional context in which regulation of broadcasting takes place and to develop from the concept of the fiduciary duty of the broadcast licensee a doctrine that would permit positive FCC enforcement of a duty to cover controversial public issues. In addition, the problems surrounding the present state of the fairness doctrine and the FCC's enforceinent of it will be considered, and some recommendations concerning the enforcement of the expanded concept developed here will be made.

\section{Prtvate and Governmental Censorship}

Because of the scarcity of broadcast frequencies, the FCC may enforce the fairness doctrine to insure that the airwaves remain open for the expression of the views of those who would not get access to the broadcast media without governmental assistance. ${ }^{20} \mathrm{Al}$ though the anount of time that a broadcast station licensee must devote to public issues lies within his discretion, ${ }^{27}$ the fairness doctrine

22. 395 U.S. 367,389 (1969).

23. Loevinger 290-98. See also Marks 999-1001.

24. Loevinger 298.

25. $I d$.

26. Red Lion Broadcasting Co. v. FCC, 395 U.S. 367, 400-01 (1969).

27. Editorializing by Broadcast Licensees, 13 F.C.C. 1246, 1247 (1949). Fol- 
"requires the broadcast licensee to afford reasonable opportunity for the discussion of conflicting viewpoints on controversial issues of public importance."28 Without soine requirement that broadcasters devote time to the coverage of public issues, the requirement of a fair and balanced presentation might result in an overall contraction of free speecl because broadcasters would simply refuse to deal with controversial issues. ${ }^{29}$ Nevertheless, soine controversy does seem to exist with regard to the obligation to broadcast controversial issues. $^{30}$ The Supreme Court, in the Red Lion case, recognized the difficulty and suggested that it could reconsider the problem if experience indicated that the fairness obligation liad "the net effect of reducing rather than enhancing the volume and quality of coverage ...."31 At the same time, the Court pointed out that "if present licensees should suddenly prove timorous, the Commission is not powerless to insist that they give adequate and fair attention

lowing the proceeding in which the FCC decided to give preferred renewal status to licensees judged to have rendered "substantial service" to the public, Policy Statement Concerning Comparative Hearings Involving Regular Renewal Applicants, 22 F.C.C.2d 424 (1970), set aside, Citizens Communications Center v. FCC, 447 F.2d 1201 (D.C. Cir. 1971), clarified, 463 F.2d 822 (D.C. Cir. 1972), the FCC undertook to define "substantial service" as including specified minimum percentages of time for local programming, news, and public affairs. See Fornulation of Policies Relating to the Broadcast Renewal Applicant, Stemming from the Comparative Hearing Process, P \& F RAdro REg. (1972 Current Service) 53:429, 431 (the FCC officially adopted this statement on Feb. 17, 1971). Had the "substantial service" policy been allowed to be followed by the FCC, it might have resulted in closer FCC control of the amount of time devoted to public affairs programming.

28. Obligations of Broadcast Licensees Under the Fairness Doctrine, 23 F.C.C. 2d 27 (1970). See Editorializing by Broadcast Licensees, 13 F.C.C. 1246, 1249, 1251 (1949). The obligation to cover public issues has been called the "absolute component" of the faimess obligation, as opposed to the "relative component" that requires a fair and balanced presentation of an issue that is covered. Malone 215. The Supreme Court apparently recognized the twofold aspect of the fairness doctrine when it spoke of "the requirement that discussion of public issues be presented on broadcast stations, and that each side of those issues must be given fair coverage." Red Lion Broadcasting Co. v. FCC, 395 U.S. 367, 369 (1969) (empliasis added).

29. Cf. Red Lion Broadcasting Co. v. FCC, 395 U.S. 367, $392-93$ (1969). See Marks 990 . The validity of the fear that broadcasters might refrain from covering controversial issues rather than subject themselves to obligations under the faimess doctrine is illustrated by the recent refusal of the television networks to accept the Allstate Insurance Company's advertisements for automobile airbags. See Hartke Gets Same Answer as Allstate, Broadcasting, August 28, 1972, at 18. But some individual stations did carry the advertisement. See Hard Way, BroADCASTING, October 16, 1972, at 5.

30. Compare Blake, supra note 3, at 78 with Malone 215 n.111.

31. 395 U.S. at 393. 
to public issues."32

Before the Red Lion case, Professor Harry Kalven criticized the fairness doctrine because it "invites the widest informal surveillance by the Commission."33 It is certainly true that the doctrine is administered in the context of a system of licensing which gives the FCC wide powers over broadcast licensees. ${ }^{34}$ But to stop there, with the prevailing image being one of government control of an enterprise engaged in the exercise of first amendinent rights, is unduly simplistic. In the first place, the FCC is subject to control by the judiciary. ${ }^{35}$ Of far more importance, however, is the fact that the "government versus private citizen" image assumes a far simpler society than actually exists. As the Supreme Court put it, "[t] $t$ here is no sanctuary in the First Amendment for unlimited private censorship operating in a inedium not open to all."36

To a large extent the controversy surrounding the permissible extent of FCC regulation of program content focuses on villains. Most people traditionally tend to view the government as the main eneiny of free speech, and thus it is easy to criticize FCC regulation. ${ }^{37}$ But the situation in our present society is far more complex than a simple confrontation between the government and private citizens who are exercising their right to free speech. In order to get a proper view, one inust understand the nature of the broadcast licensee who is supposed to be in control of the prograin content that is broadcast over the assigned station. Various writers have pointed out that the licensees find themselves subject to non-governmental pressures that inhibit thein from providing free and full coverage of

32. Id.

33. Kalven 47.

34. 47 U.S.C. $\$ \$ 301-19$ (1970). But see id. $\S 326$ (forbidding censorship by the FCC).

35. Id. \& 402 .

36. Red Lion Broadcasting Co. v. FCC, 395 U.S. 367, 392 (1969). The remark was made in the context of upholding the personal attack rules. At the same time, the sentence immediately preceding the one quoted in the text reads as follows: "Otherwise, station owners and a few networks would have unfettered power to make time available only to the highest bidders, to communicate only their own views on public issues, people and candidates, and to permit on the air only those with whom they agreed." Id. Since this latter sentence seems to apply broadiy to all issues, not just personal attacks, it would appear that the sentence quoted in the text may turn out to apply in a context somewhat broader than merely the personal attack situation.

37. See, e.g., Kalven 46-47; Pierson, supra note 18, at 17-18. See also Sullivan, supra note 3, at 768 . 
public issues. $^{38}$ As Professor Donald M. Malone has suggested, the broadcasters' primary interest is "earning money from deliberately non-controversial programming designed to appeal to large, profitable audiences." ${ }^{39}$ At the same time there is nothing in the fairness doctrine that prevents a licensee from expressing opimions on the air. ${ }^{40}$ Thus, the problem cannot really be dealt with in terms of government censorship of a private entity. Furthermore, one inust keep returning to the central point, which, as the Supreme Court indicated, "is the right of the public to receive suitable access to social, political, esthetic, moral, and other ideas and experiences which is crucial here."41 In the context of the public's right to receive information, limitations on content by the licensee becoine just as

38. See Barron, An Emerging First Amendment Right 500-02; Barrow, The Attainment of Balanced Program Service in Television, 52 VA. L. Rev. 633, 63436, 639-41 (1966); Crandall, The Economic Effect of Television-Network Program "Ownership," 14 J. LAw \& EcoN. 385, 393 (1971); Johnson, Freedom to Create: The Implications of Antitrust Policy for Television Programming Context, 8 OsGOODE HALL L.J. 10, 15 n.3; Johnson \& Westen 627; Note, $A$ Fair Break for Controversial Speakers: Limitations of the Fairness Doctrine and the Need for Individual Access, 39 Geo. Wash. L. Rev. 532, 559 (1971); Comment, We Pick 'Em, You Watch 'Em: First Amendment Rights of Television Viewers, 43 S. CAL. L. REv. 826, 827, 831-34 (1970).

39. Malone 249 (citation omitted). See also Jaffe 780, where Professor Jaffe suggests that the reason broadcasters fear a requirement that they sell time for the advertising of views on controversial issues is that they would lose large parts of their audience as well as money because of the possibility of having to give free reply time.

In a recent editorial suggesting that stations affiliated with networks establish a mechanism for consultation on a professional level, Broadcasting magazine said: "Whatever the affiliates may have to say about the control or clearance of network news programs is traditionally said between station management and the stationrelations departments of the networks. Communication on that level is certain to be affected more by business considerations than by journalistic standards or aspirations. . . E" Editorial, Professional to Professional, BrondCasting, Feb. 5, 1973, at 74. The thrust of this comment indicates that editorial considerations may be subordinated to busmess considerations. It must be recognized that a suggestion that licensees should look to non-business considerations in making editorial decsions is very different from saying that profits inhibit broadcast journalism. Indeed, it may well be that the existence of profits facilitates the broadcasting of controversial issues. See Profit Motivates Television News, Professor Finds, BROADCASTING, Jan. 22, 1973, at 32. At the same time it is not necessarily inconsistent to say that high profits permit a station to broadcast controversial programming while also saying that the quest for high profits may inhibit the broadcast of controversial programming. For the purposes of the present article, the important point is the suggestion that commercial considerations interfere with the licensee's exercise of judgment in the public interest.

40. See Malone 249.

41. Red Lion Broadcasting Co. v. FCC, 395 U.S. 367, 390 (1969). 
important as restrictions on the licensee by the government. Consequently, both the government and the licensee must be considered potential villains.

At any rate, Professor Kalven's rather simple analogy of the FCC as a chairman of a town meeting with the obligation to let all people speak with a minimum of content regulation ${ }^{42}$ is mapt and misleading. It is more accurate to suggest that the broadcast licensee is the cliairman because it is the licensee who has the power to decide who will speak on his station at any given time. The FCC is in the position of the one who decides who may be a chairman and who sets the standards, in the public interest, to be followed by a chairman.

The notion of a private entity performing a public function subject to government regulation is not at all a strange one to Aunerican government. In the area of broadcasting the interest in preserving first amendment rights makes the task sensitive and of extreme importance. But that only intensifies the problem, it does not yield the solution. To over-simplify the model, and then point to the danger of government censorship, only serves to encourage neglect of the problem; it does not solve it. A licensee is not only a private entity exercising free speech; it is also an economic entity engaged in a profit-making enterprise, and allowed to do so because it is probably better for the preservation of free speech that the direct editorial function of communications not be in the hands of the government.

Over twenty years ago Professor A. A. Berle, Jr., wrote:

The emerging principle appears to be that the corporation, itself a creation of the state, is as subject to constitutional limitations which limit action as is the state itself. If this doctrine, now coming into view, is carried to full effect, a corporation having economic and supposedly juridical power to take property, to refuse to give equal service, to discriminate between man and man, group and group, race and race, to an extent denying "the equal protection of the laws," or otherwise to violate constitutional limitations, is subject to direct legal action. ${ }^{43}$

42. Kalven 47-48. Professor Kalven writes of the "speakers" who are "licensed" by the "chairman" under an implicit standard limiting the chairman to "noncontent regulation." $I d$. at 48 . In the first place, few people would probably say that a chairman of a meeting does not regulate content. But he does suggest that the FCC could go "farther," id., and so I have used the phrase "minimum content regulation" in the text to describe his analogy.

43. Berle, Constitutional Limitations on Corporate Activity-Protection of Per- 
Of course, Professor Berle was not focusing on the problem of communications, and he did not suggest that the "emerging principle" had yet become the law. ${ }^{44}$ But his ideas illustrate that our society is too complex to be considered solely in terms of the distinction between private entities and the government. Rather, the focus should be on the rights and needs of the people; and the institutions and doctrines created to protect those rights and satisfy those needs should be judged in terms of their contribution to these goals. In the present context what must be promoted and protected is the public's right to receive all types of ideas. The faimess doctrine, and its attendant content control, should be evaluated in terms of whether it serves this function.

Another point that must be made is that the FCC is not government-it is simply a part of government operating as an imdependent regulatory commission. In that respect it does not seem warranted to assume that the FCC will abuse fundamental rights just because it appears that the government will do so. ${ }^{45}$ It does not seem particularly new or unique to suggest, at this late date, that it

sonal Rights from Invasion Through Economic Power, 100 U. PA. L. REV. 933, 942 (1952) (citation omitted).

44. See id. at 954-55.

45. Cf. Kalven 48-49; Jaffe 786. CBS News Correspondent Walter Cronkite sharply criticized the notion of review of broadcast journalism by any government panel, He said: "To place licensed broadcast medium under threat of such investigation is to place it permanently under fear of accountability to unfriendly antagonists wielding the power of legal restraint." Cronkite, supra note 7 , at 1002 . His criticism was based upon a view of governmeut reflected in his statement of the issue as

whether those who are elected to public office on partisan platforms, who represent, properly, the special imterests of their region, who by their political nature properly hold strong views on the issues of the day, should be vested with the right to say whether broadcast journalism is performing in the people's interests. Id.

His view is somewhat simplistic. FCC members are appointed by the President, with the advice and consent of the Senate. 47 U.S.C. $\$ 154$ (a) (1970). Federal judges, including Justices of the Supreme Court, are appointed in the same manner. Perhaps too much in the way of partisan considerations enters into the appointmeut process, but the issue is the creation of institutions that will protect free speech, and rather than deciding that no institution of governmeut can do the job, one might focus on developing better institutions or at least on improving the appoimtment process. See notes 136-44 infra and accompanying text. At any rate, I doubt that everyone would agree with Mr. Cronkite when he says, without any supporting references: "It is not as if there were no monitor on our performance in broadcast journalism. The newspapers have served this function well. They have proved to be, and will continue to be, severe critics of the broadcast medium. . . " Cronkite, supra note 7, at 1002. See also Note, Media and the First Amendment in a Free Society, 60 Gro. I.J. 867, 944 (1972). 
may be necessary in our complex society to utilize governmental agencies to promote and protect individual rights and liberties, even froin infringement by other parts of the government.

At the same time, one must not lose sight of the fact that many aspects of government do present a danger to free speech. When the television broadcasters, through the networks, attempted to give fair coverage to a Presidential speech on the war in Indochina by presenting commentary following it, the Vice President of the United States criticized the networks severely. ${ }^{40}$ Although the Vice President said, "I am not asking for government censorship or any other kind of censorship," ${ }^{47}$ it may well be said that such criticism by a Vice President "may frighten those already unduly timid." 48 To understand the significance of the Vice President's remarks, one inust note that he spoke at a time when broadcasters perceived a threat froin the government resulting from a new approach to license renewals, enunciated by the FCC in the WHDH case. ${ }^{40}$

46. Address by Vice President Spiro Agnew, Midwest Regional Republican Meeting, November 13, 1969, printed in 115 CoNG. REC. 34043-44 (1969). Ho was particularly critical of one network, which he said "trotted out Averell Flarriman for the occasion." Id. at 34043. To this author, at least, the networks exercised commendable discretion in giving a balanced presentation of a news event, the President's speech, and it seemed particularly appropriate to present Mr. Harriman, who, the Vice President admitted, was "[f]or ten months . . . America's chief negotiator at the Paris Peace Talks...." Id.

47. Id. at 34044 .

48. Barron, Access-The Only Choice for the Media?, 48 Tex. L. Rev. 766, $772(1970)$.

49. WHDH, Inc., 16 F.C.C.2d 1 (1969), aff'd, 444 F.2d 841 (D.C. Cir. 1970), cert. denied, 403 U.S. 923 (1971). The case is summarized in Note, FCC License Renewal Policy and the Right to Broadcast, 52 Boston U.L. Rev. 94, 95 (1972). The President of the Federal Communications Bar Association stated the problem: Regardless of the final outcome of $W H D H$ or however the case may now be categorized by the Commission or its staff, the procedural result is that every broadcaster suddenly and unexpectedly finds himself in a situation in which his license may be "up for grabs" every 3 years. Hearings on $S$. 2004 Before the Communications Subcomm. of Senate Comm. on Commerce, 91st Cong., 1st Sess., ser. 91-18, pt. 1, at 32-33 (1969) (statement of Morton H. Wilner).

At the tine, the broadcasters felt that they needed legislation in order to obtain the protection they wanted. See generally id. passim. The bill, S. 2004, 91st Cong., 1st Sess. (1969), was deferred in favor of a compromise, Policy Statement Concerning Comparative Hearings Involving Regular Renewal Applicants, 22 F.C.C.2d 424 (1970), set aside Citizens Communications Center v. FCC, 447 F.2d 1201 (D.C. Cir. 1971), clarified, 463 F.2d 822 (D.C. Cir. 1972). See 447 F.2d at 1210. Given the influence of the Presidency on the Congress, and the relationship of the Vice President to the Presidency, his remarks carried a considerably greater potential impact than the text might indicate. Cf. Hearings on S. 2004, supra, at 415 (Statement of Lee Loevinger) (Loevinger was the former FCC commissioner 
A similar instance of subtle pressure on the networks took place recently when the President of the United States took a position apparently in favor of limiting the number of reruns permitted on network prime time entertainment shows. ${ }^{50}$ Although to the public this position may seen reasonable, it is the kind of issue that seriously affects the financial interests of the broadcasters; and in evaluating what might have chilling effects on free speech, it is the potential speaker's perception that counts. ${ }^{51}$

Last Deceinber, the pressure on the networks became more open. The Director of the Office of Telecommunications Policy (OTP) in the Executive Office of the President, Clay T. Whitehead, gave a speech in which he announced that his office had submitted a license renewal bill to the Executive Branch for eventual introduction in the Congress. ${ }^{52}$ It was not so much the changes that the bill would make in the license renewal process ${ }^{53}$ that caused concern among the broad-

and was representing newspaper publishers who were hicensees of broadcasting stations, id. at 414.).

50. See The President Takes Sides Against Network Reruns, Broadcasting, Sept. 18, 1972, at 12-14. In addition to his own public statements, the President spoke through Clay T. Whitehead, the director of the White House Office of Telecommunications Policy. An examination of the relation of that Office, and implicitly the Presidency, to the FCC and Congress, is beyond the scope of this article. Such an exammation would be a useful study at this time, and may cast some light on the degree of control a President can exercise over an independent regulatory commission.

The President's position statement took the form of an endorsement of the Screen Actors Guild's campaign to limit network reruns in order to preserve work for its members. See id.

51. One magazine described the President's action as follows:

Aside from obvious political motivations (California, with 45 votes, has largest single block in Electoral College), action is seen as switch in tactics in keeping networks on their toes, substituting rerun issue for broadsides against purported slanting of news by featured network journalists. Closed Circuit: Party Favor, BroadCASTING, Sept. 18, 1972, at 5.

52. Address by Clay T. Whitehead, Indianapolis Chapter of Sigma Delta Chi Luncheon, Indianapolis, Indiana, Dec. 18, 1972, at 7. The text of the proposed bill was published in Broadcasting, Jan. 1, 1973, at 20; Television Digest, Dec. 25, 1972, at 4-5.

53. In a subsequent speech delivered to the National Academy of Television Arts and Sciences in New York, Mr. Whitehead stated that the bill would accomplish the following:

It improves the license renewal process by making four changes in the present practices: (1) it extends the term of broadcast licenses from three to five years; (2) it eliminates the requirement for a comparative hearing whenever a competing application is filed for the same broadcast service; (3) it prohibits any restructuring of the broadcast industry through the license renewal process; and (4) it prohibits the FCC from considering its own predetermined program criteria in applying the ascertainment and fairness standards of the bill. Address by Clay $T$. White- 
casters; indeed, the provisions would give the broadcasters much of what they had been seeking for a long time with regard to license renewals. ${ }^{54}$ The problem was that in his speech Mr. Whitehead suggested that the local stations should exercise control over what he alleged was biased news programming carried by the networks. ${ }^{55}$ Specifically, Mr. Whitehead said:

Station managers and network officials who fail to act to correct imbalance or consistent bias from the networks-or who acquiese by silence-can only be considered willing participants, to be held fully accountable by the broadcaster's community at license renewal time. ${ }^{56}$

Thus, the speech seems to have been an effort to put more pressure on the networks through station licensees by offering support for much of what the broadcasters want in the area of license renewal in return for their keeping a close watch on the networks. ${ }^{57}$

Unfortunately, it is easy to find other examples illustrating the danger that government poses to free speech. A congressional com-

head, National Academy of Television Arts and Sciences, New York

City, New York, Jan. 11, 1973, at 3.

The bill would make license renewal dependent on the licensee's responsiveness to the needs and interests of those in the station's local service area and on whether the bicensee "afforded reasonable opportunity for the discussion of conflicting views on issues of public importance." Broadcasting, Jan. 1, 1973, at 20; Television DigesT, Dec. 25, 1972 , at 4.

54. See Zeidenberg, The Push has Come to Shove in Broadcast Journalism, BroadCaSting, Jan. 1, 1973, at 35. Accord, FCC Commissioner Nicholas Johnson, Remarks Prepared for Delivery to the Rhode Island School of Design Conference on Television Communications and Community, Providence, Rhode Island, on Jan. 22, 1973, at 8. Furthermore, the fairness obligations contained in the bill were not new and the FCC presently has the power to enforce them. See Whitehead, Speecls of Jan. 11, 1973, supra note 53, at 3; notes 26-32 supra and accompanying text.

55. Whitehead, Speech of Dec. 18, 1972, supra note 52, at 9-12. He used the term "ideological plugola" to describe allegedly biased actions of television journalists. Id. at 9.

56. Id. at 11.

57. See Commissioner Johnson, Speech of Jan. 22, 1973, supra note 54, at 8-13. Accord, Zeidenberg, supra note 54, at 35. BroadCASTINo magazine even came out in support of the bill with the exception of the provisions relating to the enactment of the fairness doctrine, Editorial, Better the Bill than the Blather, BROADCASTING, Jan. 1, 1973, at 82, bnt distinguished sharply between the speech and the bill. Id. Of the speech the magazine said: "The Whitehead jawboning on network bias may be taken for what it is-another outburst of Nixon-administration outrage against that familiar ogre, the Eastern liberal establishment. This time, of course, it was articulated in context with talk about affiliate responsibilities and license renewal. That put a hot new lead on Spiro Agnew's old scripts." Id. 
mittee conducted a vigorous investigation into a Columbia Broadcasting Systein program entitled "The Selling of the Pentagon" and atteinpted to have the House of Representatives cite the President of CBS for conternpt when he refused to furnish the subcommittee with material other than that actually presented on the air. ${ }^{58}$ The efforts of the government to prevent the publication of the now famous Pentagon Papers ${ }^{59}$ led Professor Louis L. Jaffe to say:

The proposition that the threat of government censorship is much less than that of private censorship cannot withstand the lesson of the government's attempt to suppress publication of the Pentagon Papers. An argument of this sort can only be made by one wlro, not having lived under a system of government censorship, appears to lrave no idea what it really means. If one private person suppresses a fact there are others who may publish. Not so if the government forbids! ${ }^{00}$

There is no need here to continue with inore examples. ${ }^{61}$ The dangers of government censorship are certainly not less than those of private censorship. But, it inust be added, neither is private censorship limited to "one private person" suppressing a fact, for the broadcast media are not just private persons. ${ }^{62}$ The challenge is, therefore, to create a tradition of free speech that is suited to protection of full debate and understanding of public issues. As already stated, this author believes that it is possible to develop a doctrine that will permit an independent regulatory agency to promote free speech

58. See House Comm. on Interstate \& Foreign Commerce Proceeding Against Frank Stanton and Columibia Broadcasting System, Inc., H.R. Rep. No. 349, 92d Cong., 1st Sess. (1971); Subpenaed Material Re Certain TV News Documentary Programs, Hearings Before the Special Subcomm. on Investigations of the House Comm. on Interstate \& Foreign Commerce, 92d Cong., 1st Sess., ser. 16, 20-150 (1971).

59. See New York Times Co. v. United States, 403 U.S. 713 (1971).

60. Jaffe 786 (citation omitted).

61. One might mention, for example, growing instances of government subpoenaing newsmen to testify as to confidential sources. See Branzburg v. Hayes, 408 U.S. 665 (1972); Oelsner, Reporter's Safeguard: Bridge Case Raises Doubts About the Status of Privilege of the Press, N.Y. Times, Oct. 10, 1972, at 49, cols. 7-8; Whalen Deplores Vulnerability of News Media, Broadcasting, Oct. 2, 1972, at $41-42$.

62. Section 301 of the Communications Act of 1934 niakes it clear that licensees do not operate their stations as private owners of the frequencies. 47 U.S.C. $\S 301$ (1970). See id. $\S \S 307$ (a), 309(a). See also Red Lion Broadcasting Co. v. FCC, 395 U.S. 367, 389 (1969). These citations are certainly not a complete response to Professor Jaffe, but they do indicate that the problem is nore coniplex than the quotation admits. See note 38 supra and accompanying text. 
on the airwaves without inhibiting it. It is against the background of both private and government potential for censorship that the doctrine must be considered.

\section{FidUCIARY DUTY OF THE BROADCAST LICENSEE}

\section{General Description}

At the heart of a doctrine that would permit the FCC to promote free speech without restricting it lies the concept of the fiduciary duty of the hicensee. The Supreme Court, in Red Lion, summarized the duty as follows:

There is nothing in the First Amendment which prevents the Government from requiring a licensee to share his frequency with others and to conduct himself as a proxy or fiduciary with obligations to present those views and voices which are representative of his community and which would otherwise, by necessity, be barred from the airwaves. ${ }^{63}$

In administering a doctrine based on the fiduciary obligation, the FCC would not be in charge of program content. Instead, it would evaluate the performance of the licensee to determine whether the licensee inhibited or suppressed views on controversial subjects, on the one hand, or conducted the broadcasting station in such a way as to cover many sides of controversial public issues in a fair manner, on the other. A major problem, of course, is whether the distinction between promotion and suppression is sufficiently clear to permit a licensee to understand and fulfill the duty and the FCC to judge the licensee, without censoring him or preventing him from presenting controversial issues as they appear to the licensee based on professional judgment. The licensee must be free to present material based on his own viewpoint and the viewpoints of professional newsmen in the employ of the licensee or his prograin sources-provided that fair coverage is given to all points of view. The present author finds the distinction between promotion and suppression readily intelligible, although on any one issue there may be room for disagreement. But this is true of any first annendinent issue. ${ }^{64}$

63. 395 U.S. at 389.

64. See, e.g., Dennis v. United States, 341 U.S. 494 (1951). Some other writers also find no inconsistency between FCC examination of program content and protection of free speech. See, e.g., Jorgensen, Schwartz \& Woods, Programming Diversity in Proposals for New Broadcast Licenses, 32 Geo. Wash. L. Rev. 769, 803 (1964); Marks 1004-05. Former FCC Commissioner Lee Loevinger, who represents people "particularly interested in the protection of . . . free speech," Hear- 
In Red Lion, the Supreme Court based its decision upholding the fairness doctrine on the scarcity of broadcast frequencies. ${ }^{65}$ The Court refrained from considering the argument that, regardless of scarcity,

Congress does not abridge freedom of speech or press by legislation directly or indirectly multiplying the voices and views presented to the public through time sharing, fairness doctrines, or other devices which limit or dissipate the power of those who sit astride the channels of communication with the general public. ${ }^{66}$

Nevertheless the concept exists and deserves consideration. The basis of the case aside, Loevinger found that the Supreine Court, in Red Lion, "converted the responsibilities of broadcasting, with respect to information, into legal duties, and it has elevated these duties to constitutional status."

The concept of the fiduciary duty of the broadcast licensee has its origins in the language, as opposed to the actual results, of FCC decisions. As early as 1945 , the FCC spoke of

the duty of each station licensee to be sensitive to the problems of public concern in the community and to make sufficient time availa-

ings on S. 2004, supra note 49 , at 414 , described the duty as follows:

The right of free speech by broadcasting belongs to the public, not to the licensee, and the licensee is a proxy for the public with a fiduciary duty to insure the fair presentation of all viewpoints. It is all viewpoints that are entitled to be lieard, not all individuals or all spokesmen, except in the cases, specified by statute or rule, involving political candidates or personal attacks. The FCC may specify procedures and applications of this fiduciary duty, but it may not constitutionally abridge the right of the public to receive the full range of views and information which the licensee's initiative discovers or responsible elements of the community demand or offer. . . . Loevinger 297.

65. 395 U.S. at $400-01$. Loevinger discussed the Court's basis for the decision as follows:

The scarcity argument with respect to broadcasting facilities logically militates as strongly against government snppression througli the licensing power as in favor of it. The theory and spirit of the first amendment, as repeatedly stated by the Supreme Court, is that government action must not be exerted to suppress any expression, no matter how hateful or noxious in the view of officials, except within certain limited and defined categories. Where the opportunity for expression is unlimited, as in private speech or writing, government action to suppress some particularly objectionable expression may have a relatively limited effect on the general discourse. But where the opportunity for expression is limited and requires a government license, any action by government to suppress expression through the licensed facilities or to favor or disfavor particular kinds of expression will necessarily liave greater influence and impact on all expression over similarly liccnsed facilities. Since the first amendinent commands government neutrality with respect to the content of all types of cxpression, government action to control the content of expression on limited and licensed facilities is peculiarly inappropriate. Loevinger 283.

66. 395 U.S. at $401 \mathrm{n} .28$ (citation omitted).

67. Loevinger 297. 
ble, on a nondiscriminatory basis, for full discussion thereof, without any type of censorship which would undertake to impose the views of the licensee upon the material to be broadcast. . . .08

When, four years later, the FCC approved the right of licensees to editorialize, the majority opinion stated that "the licensee is a trustee impressed with the duty of preserving for the public generally radio as a medium of free expression and fair presentation." 00 The FCC also recognized that the "right of the public to be informed . . . is the foundation stone of the American system of broadcasting." "70 Chief Judge Bazelon of the District of Columbia Circuit Court of Appeals recently echoed that statement when he found that "central to the fairness doctrine is the promotion of informed decision-making by the public. ..."71 In order to keep the public informed, the FCC made it clear in its opinion that the licensees "have an affirmative duty generally to encourage and iniplement the broadcast of all sides of controversial public issues over their facilities. . ."72 In fulfilling this affirmative duty, the FCC suggested that the licensees must play "a conscious and positive role in bringing about balanced presentation of the opposing viewpoints." 73

In light of this language, the licensee occupies a very special and important position in society. $\mathrm{He}$ is supposed to be a specialist in the education of the public through the broadcasting media. Yet when it comes to network programming at least, the licensees do not appear to fulfill that function. ${ }^{74}$ But the question here is not whether compliance with the duty is being enforced, but whether such compliance can be enforced vigorously and the duty developed through such enforcement. It would seem that, at a minimum, the language implies that decisions on programming should be based not only on the need to make a profit, but also on the need to inform the public on important issues. With the ability to 1nake a profit comes the obligation to engage in an educational and informative role. A licensee should be inore than a busimessman; he should be a professional who

68. United Broadcasting Co., 10 F.C.C. 515,517 (1945).

69. Editorializing by Broadcast Licensees, 13 F.C.C. 1246, 1258 (1949).

70. Id. at 1249.

71. Retail Store Employees Union, Local 880 v. FCC, 436 F.2d 248, 257 (D.C. Cir. 1970).

72. Editorializing by Broadcast Licensees, 13 F.C.C. 1246, 1251 (1949).

73. Id. See Friends of the Earth, 23 P \& F Radio Reg. 2D 917, 920 (1972).

74. Barrow, Balanced Program Service, supra note 38, at 641. See also id. at 635-36, 639-41; Note, First Amendment Rights of Television Viewers, supra note 38 , at 832 . 
can at least put together an organization that would make legitimate efforts to produce or purchase programs that informed as well as entertained and attracted high ratings.

\section{Discretion of the Licensee}

Implicit in the concept that a licensee should be something of a professional is the idea that he should have broad discretion. The FCC speaks of the licensee having to make "reasonable judgments in good faith."75 To govern its duty to judge the licensee, the FCC articulated a standard that is not unknown to lawyers, namely that

the Commission's role is not to substitute its judgment for that of the licensee as to any of the ... programming decisions, but rather to determine whether the licensee can be said to have acted reasonably and in good faith. ${ }^{76}$

More recently, in initiating an overall review of the fairness doctrine, the Commission said of the licensee's duty under the fairness doctrine: "The individual licensee las the discretion, and indeed the responsibility, to determine what issues slould be covered, how much time should be allocated, which spokesinen should appear, and in what format. . . ."77 Although this statement may indicate a retreat from the standards expressed in prior years, ${ }^{78}$ it does reflect that any duty on the licensee entails a fair amount of discretion. ${ }^{79}$

The point of this discussion is not that such a standard exists and is presently enforced; rather, the point is that the concept of a licensee who is required to use judgment to inform the public on

75. Applicability of the Fairness Doctrine in the Handling of Controversial Issues of Public Importance, 40 F.C.C. 598, 599 (1964).

76. Id.

77. The Handling of Public Issues Under the Fairness Doctrine and the Public Interest Standards of the Communications Act, 30 F.C.C.2d 26, $27-28$ (1971).

78. See id. at 35-36 (concurring opinion, Commissioner Nicholas Johnson).

79. Perhaps $a$ better statement is the following one the Commission made when it first approved editorializing. At that time the FCC said:

The licensee will in each instance be called upon to exercise his best judgment and good sense in determining what subjects slould be considered, the particular format of the programs to be devoted to each subject, the different shades of opinion to be presented, and the spokesmen for cach point of view. ... Undoubtedly, over a period of time some licensees may make honest errors of judginent. But there can be no doubt that any licensee honestly desiring to live up to its obligation to serve the public interest and making a reasonable effort to do so, will be able to achieve a fair and satisfactory resolution of these problems in the light of the specific facts. Editorializing by Broadcast Licensees, 13 F.C.C. 1246, 1251-52 (1949). 
controversial issues is neither new nor incapable of statement. As Professor Barron pointed out some time ago, if the FCC enforced these obligations vigorously, "fairness" would become "at least as manageable a concept as . . . 'unfair labor practice' and 'unfair competition. . . . $\$ 80$ Furthermore, the concepts of honest judgment and good faith efforts do not lack ineaning. Many lawyers can recognize the difference between their good faith view of what the case law holds and what they would like the law to be, either in terms of their client's interest or the public interest. In our society it is necessary and important to make sophisticated judgments. These judgments are implicit in the everyday life of the lawyer, and they are not any less difficult than having to distinguish between a licensee who has made good faith efforts to present a reasonable amount of informative programming subject to the fairness requirement and the licensee who never falters from the pursuit of the single-minded purpose to maximize profits. Of course, there may be close cases, and the fact that the standard may be flexible nay make it subject to abuse; but, as the FCC emphasized, the possibility of abuse is no reason to abandon a standard. ${ }^{81}$ In this regard, one inust consider that the FCC maintains procedural standards and that its judgments are subject to judicial review. ${ }^{82}$

Building on language already in FCC opinions, the FCC could evaluate licensees to decide whether they had made good faith efforts to devote reasonable time to the presentation of important public issues of a controversial nature. ${ }^{83}$ This is not a situation in which a licensee needs such a clear standard that he can limit his perfornnance to the bare minimum necessary to fulfill the obligation imposed upon him. Such an effort would not satisfy the good faith requirement.

80. Barron, In Defense of "Fairness," supra note 3, at 34.

81. Editorializing by Broadcast Licensees, 13 F.C.C. 1246, 1256 (1949).

82. Id. Judicial review of FCC decisions in this area would be vigorous. See Brandywine-Main Line Radio v. FCC, 473 F.2d 16, 80 (D.C. Cir. 1972) (concurring opinion, Wright, J.), petition for cert. filed, 41 U.S.L.W. 3488 (U.S. March 5, 1973) (No. 72-1207). Judge Tamm's opinion in that case, which affirms a denial of a license renewal, extended for almost 45 pages. See note 111 infra.

83. In a sophisticated society, standards should not be limited to what can be stated simply. Broadcasters perform an important and sensitive function in our society. As Chief Justice Burger wrote shortly before assuming his present position as Chief Justice of the Supreme Court:

The infinite potential of broadcasting to influence American life renders somewhat irrelevant the semantics of whether broadcasting is or is not to be described as a public utility. By whatever name or classification, broadcasters are temporary permittees-fiduciaries-of a great public resource and they must meet the highest standards which are embraced im the public interest concept. Office of Communication of the United Church of Christ v. FCC, 425 F.2d 543, 548 (D.C. Cir. 1969). 
Licensees with network affiliations should be demanding that the networks give them more controversial programming. ${ }^{84}$ All licensees should seek to obtain controversial programming, and, of course, fulfill their obligation to determine whether they must supplement the programs obtained in order to comply with the fair coverage requirement. ${ }^{85}$ There is a big difference between a licensee who presents controversial programming during prime time and the licensee who fills the Sunday morning schedule with public affairs programming so that he will meet the minimum standards of public service. Naturally, many licensees will fall within a middle ground, but if a licensee does devote some portion of prime time each evening to controversial programming, as well as having controversial programming on at various times throughout the schedule, and makes good faith efforts to give fair coverage to important issues even if it means sacrificing more lucrative programs, it should not be hard to find that he complied with his obligation. Licensees who make a policy of accepting editorial advertising rather than refusing it, and licensees who seek out controversial guests rather than finding excuses to keep them off the air ${ }^{86}$ can also be considered as making good faith efforts to fulfill their obligations. One can distinguish between entertainment programming that simply mirrors only that image of the commumity to which the fewest number would object and programming, be it entertainment or any other kind, that probes issues of vital concern to society and raises the kinds of hard questions that

84. Cf. F. Friendly, Due to Ctrcumstances Beyond Our Control 223-24 (1967). For a good discussion of the problems of getting controversial programs of public importance covered by the networks, see generally id. passim.

85. Even the FCC has recognized that licensees may not rely on the sources of their programs to meet the fair coverage obligation. See Applicability of the Fairness Doctrine in the Handling of Controversial Issues of Public Importance, 40 F.C.C. 598,605 (1964).

86. The FCC seems to recognize the problen with regard to the possibility of excuses for avoiding controversial gnests. It recently stated:

In the Report on Editorializing by Broadcast Licensees, 13 F.C.C. 1246 (1949), in which the basic requirements of the fairness doctrine were set forth, we held that a broadcast licensee was not required to insure that both sides of an issue would be lieard before any time could be afforded for discussion of the issue. A contrary holding, we pointed out, would tend to limit discussion to formats where both sides were present and would give the spokesmen for one point of view an effective veto power over presentation of the issue if they refused to appear. On the other hand, we also rejected the proposition that a licensee's sole obligation was to refrain froin suppressing or excluding responsible points of view. Rather, we made clear that a licensee has an affirmative duty to encourage and implement the broadcast of conflicting viewpoints on controversial public issues. Friends of the Earth, 23 P \& F RADIO REG. 2D 917, 920 (1972). 
go to the heart of the difficult issues that divide the society and provoke controversy.

Professor Roscoe L. Barrow suggested that the FCC could adopt criteria to aid in the determination of what is a controversial issue and what is an issue of public importance. Writing in 1968, he stated:

Among the criteria which might be considered are degree of contentiousness, purpose and effect of the espousal, nature of disagreement between the espouser and the group seeking to reply, value of clarification to community understanding of the issue, the societal values underlying the issue, and the importance of the decision to society . . . . ${ }^{87}$

It is not that these criteria would determine the issues. Indeed, the present author would doubt that the determination of whether an issue is controversial should depend on whether a group sought to reply, although, of course, that fact should be of some significance. The point is that criteria can be developed to identify controversial issues of public importance, and that the FCC can therefore evaluate whether licensees devoted a reasonable amount of time to such issues and made good faith efforts to cover them fairly.

Implicit in this argument, of course, is the idea that the determination of a controversial issue may involve complexities of a somewhat greater order than the traditional determmation of whether government interfered with free speech. The key point here is that the licensee is being evaluated as to his good faith efforts to fulfill a fiduciary duty and that in fulfilling that duty he will be given a fair amount of discretion. ${ }^{88}$

87. Barrow 542-43.

88. Id. at 543. Cf. David Hare, 24 P \& F RAdio REg. 2D 807, 810 (1972), where the FCC said:

Initially, whether or not any given program is a controversial issue of public importance is determined by the individual licensee. The Commission will, of course, review the licensee's decision gemerally only to determine whether the licensee acted reasonably under all the circumstances.

See also Barrow 487-88, where it is stated:

In evaluating the inhibitory effect of the fairness doctrine on broadcast joumalisin, consideration should be given to the procedure followed by the Commission in handling violations. The Commission does not monitor broadcasts for violations but acts only upon a complaint by listeners, and if a violation is found, the broadcaster is merely asked to broadcast a contrasting viewpoint.

Of course this statement would not apply to an overall failure of a bicensee to broadcast controversial programming during the term of the license if the doctrine discussed by the present author were to be enforced. 


\section{Protection of the Licensee}

Another aspect of the problem is whether a sufficient standard can be articulated to protect the licensees in their presentation of controversial programming. In this area the distinction between promotion and suppression, which seems reasonably clear, would serve to permit the protection of the licensees. In renewing a broadcast license in the face of complaints about the broadcasts of "offensive" poetry, a play by Edward Albee, "The Zoo Story," and a discussion by homosexuals of their attitudes and problems, the FCC said:

We recognize that as shown by the complaints here, such provocative programing as here involved may offend some listeners. But this does not mean that those offended have the right, through the Commission's licensing power, to rule such programing off the airwaves. Were this the case, only the wholly inoffensive, the bland, could gain access to the radio microphone or TV camera. ... In saying this, we do not mean to indicate that those who have complained about the foregoing programs are in the wrong as to the worth of these programs and should listen to them. This is a matter solely for determination by the individual listeners. Our function, we stress, is not to pass on the merits of the program-to commend or to frown. Rather . . . it is the very limited one of assaying, at the time of renewal, whether the licensee's programing, on an overall basis, has been in the public interest and, in the context of this issue, whether lee has made programing judgments reasonably related to the public interest. . . . ${ }^{89}$

The FCC also approved the application of the principle in the foregoing quote in dealing with complaints about broadcasts containing anti-Semitic material ${ }^{90}$ and derogatory material about American Indians. ${ }^{91}$

89. Pacifica Foundation, 36 F.C.C. 147, 149 (1964). Recently, the FCC had occasion to comment on two controversial programs. The Commission said:

We note, however, that the networks are to be commended for this type of broadcast (e.g., the CBS "Harvest of Shame"; the recent NBC Migrant Workers program). For, these programs typify the commitment to "robust, wide-open debate" upon which this nation depends. They do not constitute simply a measured, careful assessment of where other entities or public opinion are, but rather demonstrate a devotion to leadershipto breaking open forcefully, effectively, and fairly issues of great importance. It goes without saying that this kind of effort is called for, whatever the effect on the broadcast media advertiser. Friends of the Earth, 24 F.C.C.2d 743, 751 (1970), remanded on other grounds, 449 F.2d 1164 (D.C. Cir. 1971).

90. United Federatiou of Teachers, 17 F.C.C.2d 204, 208-09 (1966). Cf. Atlanta NAACP, 25 P \& F RADio REg. 2D 54 (1972).

91. David Hare, 24 P \& F Radio REg. 2D 807, 809-10 (1972). 
This discussion is not aimed at setting forth the FCC's policy. Indeed, it is hard to square the policy as set forth here with the FCC's decision declaring a forfeiture against an educational radio station because of the broadcast of an interview with a person who used a great many so-called "dirty" words." Even there, however, the FCC reaffirmed its policy of "promoting robust, wide-open debate." controversial material, the distinction between promotion and suppression is clear. Indeed, in the case involving the dirty words, it seems clear that the FCC was acting to suppress the free speech of people whose speech habits offend some. ${ }^{94}$ There is a difference between prohibiting offensive programming and regulation to promote diversity and access. ${ }^{05}$ The fact that there exist people in positions of power who would like to suppress offensive programming should not be permitted to obfuscate that distinction.

Given that distinction, and given the idea that promotion of speech need not include limitation of controversial content, the FCC could enforce a duty that would require licensees to present substantial amounts of controversial programming. The duty would not go to requiring broadcasters to present material on any particular issues, nor would the FCC need to become involved in the point of view presented. Rather, the FCC would evaluate the performance of the licensee based on whether the station contributed to the discussion of controversial issues of public importance in a substantial manner. The standard would not have to be specific. The licensee would be treated as a trustee with a high degree of duty to utilize his discretion to inform the public. The evaluation would be based on whether the discretion was used in good faith to present controversial programming as distinguished from the use of discretion to minimize controversy in order to avoid offending listeners. By enforcing discretion rather than dictating programming content, the FCC would avoid suppressing speech or interfering with editorial judgments made by the licensee. Because the licensee is a fiduciary who should be held to a standard of good faith rather than being permitted simply to fulfill a "bare minimum" standard nec-

92. WUHY-FM, Eastern Educational Radio, 24 F.C.C.2d 408 (1970).

93. Id. at 415 .

94. See id. at 417-21 (dissenting and concurring statement, Commissioner Cox).

95. See Note, Morality and the Broadcast Media: A Constitutional Analysis of FCC Regulatory Standards, 84 HARv. L. Rev. 644, $698-99$ (1971). 
essary to retain a license, ${ }^{96}$ guidelines set by the FCC would not result in directly shaping the program content. Rather, the licensee should be presenting an amount of controversial programming dealing with issues of public importance sufficiently in excess of any minimal guidelines so that decisions concerning any one program need not consider the FCC standards. And, if by some chance there appears a new applicant at renewal time who, in comparison with the licensee, appears to be better able to fulfill the fiduciary duty, the licensee may lose his license. But such competition is already an integral part of the licensing system, ${ }^{97}$ and the doctrine of the fiduciary duty, as proposed here, could be incorporated into it. ${ }^{98}$

\section{FCC's FAILURE To ENForCe THE FAIRNESS Doctrine AND THE NEED FOR POSITIVE REgULATION}

\section{FCC Practice}

Recently, in discussing the coverage of environmental issues, the FCC said:

While we have stressed that the broadcaster has large discretion in choosing and covering controversial issues of public importance, it would be no more reasonable for broadcasting to ignore these burning issues of the seventies-which may determine the quality of life for decades or centuries to come-than it would be to ignore the issue of Vietnam or the issue of racial unrest in communities racked by this problem. ${ }^{99}$

In a footnote to that statement, the FCC stressed that the licensees retained discretion as to what to cover and the methods of presentation, and reaffirmed that wide areas remained for judgment by thein. ${ }^{100}$ One would assume that that judgment would be limited to judgment leading to extensive coverage. ${ }^{101}$ But in the above case the FCC refused to evaluate the licensee's exercise of judgment de-

96. See Greater Boston Television Corp. v. FCC, 444 F.2d 841, 860 (D.C. Cir. 1970), cert. denied, 403 U.S. 923 (1971).

97. See id. See also 47 U.S.C. $\$ \S 301,307$ (d), 308-09 (1970).

98. See S. 2004, 91st Cong., 1st Sess. (1969).

99. Friends of the Earth, 24 F.C.C.2d 743, 750-51 (1970), remanded, 449 F.2d 1164 (D.C. Cir. 1971).

100. 1 d. at 751 n.9.

101. Cf. Note, FCC License Renewal Policy, supra note 49, at 138, where it is said: "The controlling principle of the Fairness Doctrine, that the public has the right to have the mass media function consistently with the first amendment, is offset by the right of the licensee to control and manipulate discussion to the derogation of those rights." 
spite the complaimt charging imadequate coverage..$^{102}$ Instead, the FCC suggested that the matter would be considered, upon appropriate complaint, in a license renewal proceeding where the entire record of the licensee with regard to the coverage of controversial issues could be considered. ${ }^{103}$ Were the FCC engaged in a process of vigorous enforcement of licensees' fiduciary obligations at renewal, one would not take the skeptical view of sucli a statement; such a view may be justified, however, in the liglit of FCC practice.

This kind of dichotomy between actions and words seems typical of the FCC's behavior. In sharply criticizing the FCC for its failure to enforce the fairness doctrime, ${ }^{104}$ Professor Barrow was inoved to say: "Some of the most beautiful language to have flowed from the pen of government has come to us through the Commission's fairness decisions . . .."105 Despite the high-minded language, the FCC does not inspire confidence in its desire to enforce the duty of the broadcasters to give fair coverage to controversial issues of public importance. ${ }^{106}$

There is one case, Brandywine-Main Line Radio (WXUR), ${ }^{107}$ in which a broadcast license was not renewed primarily because of

102. Friends of Earth, 24 F.C.C.2d 743, 751 (1970).

103. Id.

104. Barrow 469-72.

105. Id. at 469.

106. See Barron, In Defense of "Fairness," supra note 3, at 35; Marks 976; Note, Concepts of the Broadcast Media Under the First Amendment: A Reevaluation and a Proposal, 47 N.Y.U.L. Rev. 83, 97-98 (1972); Note, Fairness Doctrine, supra note 3 , at 1250 . In his concurring opinion, Commissioner Johnson stated: "It is becoming increasingly clear that the Fairness Doctrine, rather than serving as a means of satisfying legitimate demands for access, is increasingly functioning as an 'Unfairness Doctrine' by legitimizing broadcaster frustration of those demands. . . ." The Handling of Public Issues Under the Fairness Doctrine and the Public Interest Standards of the Communications Act, 30 F.C.C.2d 26, 35 (1971). Commissioner Johnson was speaking of a right of access where complainants seek either the right to reply to material, including commercials broadcast or the carriage on the station involved of particular counter-advertisinents. See, e.g., Democratic Nat'l Comm. v. FCC, 460 F.2d 891 (D.C. Cir.), cert. denied, 409 U.S. 843 (1972); Friends of the Earth v. FCC, 449 F.2d 1164 (D.C. Cir. 1971), remanding 24 F.C.C.2d 743 (1970); Green v. FCC, 447 F.2d 323 (D.C. Cir. 1971); Neckritz v. FCC, 446 F.2d 501 (9th Cir. 1971). Although the main concern of this article is with the enforcement of a high degree of duty on the licensee to present controversial issues fairly, the author thinks that the right of access branch of the fairness doctrine is a useful supplement to the licensee's duty. See note 11 supra. At the same time it should be noted that advocates of access seem to recognize the need to maintain the trustee system of broadcasting. See Johnson \& Westen 583-84.

107. Brandywine-Main Line Radio, Inc., 24 F.C.C.2d 18 (1970), aff'd on other grounds, 473 F.2d 16 (D.C. Cir. 1972) (per curiam), petition for cert. filed, 41 
the station's failure to comply with the fairness doctrine. The FCC also found in Brandywine that the licensee did not fully inform the FCC, failed to adhere to its representations concerning program plans, ${ }^{108}$ and "made no efforts during the relevant license period which were sufficient to meet its public interest obligation of ascertaining the community's needs and interests." ${ }^{109}$ Nevertheless, the FCC found that the "failures by the licensee to afford a fair forum for the discussion of contrasting views on controversial issues of public importance and to afford opportunities to reply to personal attacks" were sufficient to deny renewal. ${ }^{110}$ The Court of Appeals for the District of Colunbia Circuit affirmed the action of the FCC, and, in a lengthy opinion, Judge Tamm said:

U.S.L.W. 3488 (U.S. March 5, 1973) (No. 72-1207). See note 111 infra.

Where a fairness violation was combined with an attempt at concealment, the FCC denied renewal of a license. Milton Broadcasting Co., 24 P \& F RADIo REG. 2D 369 (1972). On the other hand, there seems to be a tendency on the part of the FCC to resort to short-term renewals instead. In one recent case, not based on fairness, the FCC found that the licensee's performance had "been marked by serious deficiencies." Medford Broadcasters, Inc., 24 P \& F RADIo REG. 2D 359, 365 (1972). Writing for the FCC, Commissioner Reid said: "This licensee has paid insufficient attention to matters pertaining to station operations, and he has delegated licensee responsibilities and obligations to an intolerable degree." Id. Nevertheless, the FCC found "public interest considerations here which justify a short term renewal." Id. While this last case did not involve a fairness problein, it illustrates the Commission's use of the device even when a licensee's actions have been found to be "intolerable." In the case of one licensee, Lamar Life Broadcasting Co., the Court of Appeals for the District of Columbia remanded the proceeding to the FCC on a standing issue, after the latter had granted Lamar Life a short term renewal of its broadcast license for WLBT-TV in Jackson, Mississippi. Office of Communication of the Church of Christ v. FCC, 359 F.2d 994 (D.C. Cir. 1966). See M. Minitz \& J. Cohen, Amerrca, Inc. 238-39 (1971). Nevertheless, on remand the FCC renewed the license for a full three-year term and the court of appeals was forced to direct the FCC to vacate the renewal and invite applica. tions for the kicense. Office of Communication of the Church of Christ v. FCC, 425 F.2d 543 (D.C. Cir. 1969). In writing the court's opinion, Judge (now Chief Justice) Burger indicated the insensitivity of the FCC to its obligations that is reflected in the short term renewal process when he said:

When the matter was again before the Commission on our remand, therefore, it was in a posture that the hicensee had yet to demonstrate that it was in the public interest for the license to be renewed. This was a less favorable posture for the licensee than would have been the case absent the "probationary hicense" grant. This is important, but its significance seems to have eluded the hearing Examiner and the Commission as well. . . Id. at 545 .

108. 24 F.C.C.2d at $28-32$.

109. Id. at 34 .

110. Id at 28. A perusal of Appendices A and B to the FCC's opinion reveals that the violations during the monitored weeks were particularly egregious. See id. at 35-37. 
The alleged violations of fairness and personal attack rules are fully documented. The abuses are flagrant. The sanctions borne of the litigation were based on continuous refusals by the licensee to meet its obligations. . . . .111

111. 473 F.2d 16, 60 (1972). Judge Tamm also said:

The Commission has made no attempt to influence WXUR's programming or censor its programming in general or specifically. Had the licensee met the obligations required of it we have no reason to believe that Brandywine would lave met with any difficulty. The law places requirements on licensees as fiduciaries. Failure to live up to the trust placed in the hands of the fiduciary requires that a more responsible trustee be found. . . I Id.

At first, Chief Judge Bazelon concurred in affirming the FCC decision "solely on the ground that the licensee deliberately withheld information about its programming plans. A full statement of his views will issue at a later date." Id. at 63 . Judge Wright concurred "on the ground that substantial evidence supports the Commission's fimding that appellaut misrepresented its program plans and thus consciously deceived the Commission. . . ."Id. Judge Wright also said:

If this case did not involve an unpopular fundamentalist preacher, for me it would be an easy one indeed. . . .

But because the Commission's ruling has the possible effect of suppressing the ventilation of views with which there might be substantial disagreement, its action denying renewal of the license requires particularly careful scrutiny. As Judge Tamm's opinion makes clear, in such a case it is not enough simply to find that substantial evidence in the record taken as a whole supports the Commission and there was no abuse of discretion. In these circumstances the court itself sloould make its own evaluation of the evidence to insure that First Amendment freedoms of the licensee and the public are fully and fairly taken into account in the decision making process. ... So doing, I cannot say that the Commission erred in denying the renewal application in this case. Id.

After the first opinion was filed, Chief Judge Bazelon decided to dissent. 473 F.2d 63 (1972) (per curiam). He said that the case was primarily one involving fairness, and that it presented "a prima facie violation of the First Amendment." Id. He stated that the "constitutional validity of each and every application of the [fairness] doctrine must be tested on its own, on a case-by-case basis." Id. at 71 (footnote omitted). He also questioned the continuing validity of the scarcity rationale on which Red Lion Broadcasting Co. v. FCC, 395 U.S. 367, 396-401 (1969), was based. 473 F.2d at 75-78. His change of mind seemed to be based $\mathrm{m}$ part on his realization that even the deception issue was "inextricably bound up" in matters relating to the fairness doctrine. Id. at 80 . He concluded that the case should be remanded to the FCC for a "searching inquiry into factual issues and alternative policies raised within the constitutional framework outlined" in his opinion, id. at 64 , and in the context of the FCC's present proceeding dealing with fairness. Id. at 79. (The FCC's proceeding, The Handling of Public Issues Under the Fairness Doctrine and the Public Interest Standards of the Communications Act, 30 F.C.C.2d 26 (1971), is discussed in notes 114-19 infra and accompanying text.) At one point in his dissentmg opinion Judge Bazelon asked: "Ought we not instead focus our attention on how we can make the cable medium economically accessible to those who assert a right to use it?" 473 F.2d at 76 (footnote omitted).

Judge Wright wrote another opinion in which he made clear that his concurrence in the court's judgenent was based solely on the ground of deception. Id. at 80. He also said that Judge Tamm, who concurred im this opinion of Judge 
Thus, the result in the case, given the need to provide fair coverage of issues that are presented on the air, is not disturbing. What is disturbing is that the case stands practically alone, and that it appears that the FCC will enforce the doctrine vigorously against a station licensee broadcasting extremely controversial material, but does not seen to act vigorously against licensees who broadcast only the bland type of programs. ${ }^{112}$ To act against a station engaged in the expression of controversial views, while prounoting the coverage of public issues only with encouraging words, simply reinforces the behavior of licensees who try to avoid controversy as much as possible. ${ }^{113}$

The FCC recently instituted "a broad-ranging inquiry into the efficacy of the fairness doctrine and other FCC public interest policies."114 Commissioner Johnson concurred, saying, "[n]eedless to say, the law couldn't be any worse than it now is; it is unlikely the Inquiry will do much inore harm." 115

In its first decision under the notice, ${ }^{116}$ the $\mathrm{FCC}$ refused to extend an "equal time" or equal opportunity requirement similar to that which applies to political speeches during election campaigns to speeches of the President of the United States. ${ }^{117}$ Once again the FCC, although failing to impose any new requireinents on licensees, set forth encouraging words. ${ }^{118}$ Once again the FCC reaffirmed its basic principle regarding control of content, namely that the licensee

Wright, would affirm the FCC on that ground also. Therefore, he pointed out, the ground of deception forms the sole basis for the court's judgment. Id. at 81 . Thus, said Judge Wright, "we avoid plunging into the constitutional 'thicket that is the fairness doctrine." Id. Judge Wright also seemed to feel that the opportunity should be given to the FCC to reevaluate the fairness doctrine. See id.

112. Note, FCC License Renewal Policy, supra note 49, at 138.

113. See id. at 137.

114. The Handling of Public Issues Under the Fairness Doctrine and the Public Interest Standards of the Communications Act, 30 F.C.C.2d 26 (1971). Recently, FCC Commissioner Wiley was reported to have suggested that an FCC task force on deregulation might suggest some "experiments" such as abrogating the fairness doctrine in an area where there were many stations serving different audiences. Shanahan, F.C.C. Is Reducing Governnent Role in Broadcasting, N.Y. Timies, Nov. 3, 1972, at 1, col. 4, \& at 78, col. 6 .

115. The Handling of Public Issues Under the Fairness Doctrine and the Public Interest Standards of the Communications Act, 30 F.C.C.2d 26, 36 (1971) (conconcurring opinion, Commissioner Jolunson).

116. The FCC divided the mquiry into four parts. See id. at 26.

117. The Handling of Public Issues Under the Fairness Doctrine and the Public Interest Standards of the Commumications Act, 24 P \& F RADro REg. 2D 1917 (1972).

118. Id. at 1925, 1933. 
is the person who must control the programming and must exercise good faith efforts to discharge a fiduciary obligation. ${ }^{110}$

\section{Enforcement of the Duty}

One cannot quarrel with the FCC's policy that in order to keep the public informed the licensee must have wide discretion. In the area of radio and television communications, there is need for a high degree of skill and creativity as well as the need for the professional qualities of journalism. But little will be accomplished in achieving widespread compliance with even the stated goals of the FCC unless it undertakes to discipline licensees who fail to make good faith efforts to cover controversial issues. Licensees operate in a commercial context, and the FCC must serve as a countervailing force to encourage such programming in the face of licensee efforts to attract the largest audience and earn the highest profits. ${ }^{120}$ The broadcasters, of course, argue that any pressure from the FCC in any way relating to content constitutes an abridgment of their first amendment rights. That contention has been aptly characterized in the following language:

[S] uch arguments seek to use the first amendment as a screen behind which many broadcasters may engage in the activity most important to them-earning money from detiberately noncontroversial programing designed to appeal to large, profitable audiences. ${ }^{121}$

Thus, if the fiduciary duty is to have any meaning, the FCC must enforce it. The enforcement of such a duty does not mean abridgment, but rather promotion, of speech. The process depends upon a division between the FCC and the licensee that leaves the licensee with full discretion to carry controversial issues and full discretion with respect to the details of programming. But that discretion cannot be discretion to refuse altogether to present controversial issues. It is here that the licensee must be held to the standard of "good faith efforts" to fulfill the obligations imposed upon those

119. Id. at 1926, 1929.

120. See Note, Regulation of Program Content by the FCC, 77 HARv. L. Rev. 701, 716 (1964). Accord, Marks 1001, where it is stated:

Congress intended that broadcasting serve the public's needs, not merely the private interests of the licensee. Since program content is presently determined by licensee profit potential, not by the needs of the various groups in the community, the Commission must build the need to present "better" programs into broadcasting's corporate model of profit maximization-station managers and network executives must believe, as they plan their respective schedules, that if insufficient time is devoted to meeting public service obligations, station licenses will not be renewed.

121. Malone 249 (citation omitted). See Barrow 486-87. 
who exercise control over an important commumications medium, subject to a license and under a statute that prohibits those without a license from competing. ${ }^{122}$ The best way to enforce the duty is probably through the license renewal procedures. ${ }^{123}$ It is in an overall evaluation of the licensee's performance that a good faith efforts test can best be applied. This is not to say that the FCC should not continue to hear complaints about individual programs on the ground that the station failed to give fair coverage to a particular issue. ${ }^{124}$ Rather, froin the standpoint of improving the overall coverage with regard to both amount and fairness, it is suggested that an overall evaluation works best to combime the goals of stimulating nore and better controversial programming without inhibiting the licensee from performing his professional duties to provide robust, wide-open programming. If the kind of professional programming that best serves the needs of the public is to be encouraged, the licensee should be insulated as much as possible from detailed regulation by the FCC. At the same time, the recognition of licensee discretion should not be used as a device to permit licensees to avoid their obligations.

It has been suggested that because of broadcasters' commercial notivations, it would be difficult to enforce the requirement that broadcasters cover controversial issues, at least without a conflict with first amendment values. ${ }^{125}$ But, because of the FCC's powers, broadcasters are so extremely responsive to the FCC that one can

122. See 47 U.S.C. $\$ 301$ (1970).

123. See Marks 1001-04, where he proposes a stricter license renewal standard and discusses some of the details that might be involved in such an evaluation process. While those details may be instructive as to what the FCC might consider, the present author beheves that a good faith standard, if enforced, would serve the purpose without inhibiting good faith efforts by hicensees to be creative and to take risks in presenting controversial programming.

124. The FCC procedure for handling faimess complaints is set forth in Apphicability of the Fairness Doctrine in the Handling of Controversial Issues of Public Importance, 40 F.C.C. 598, 600 (1964). See also FCC, The Public and Broadcasting: Broadcast Procedure Manual, 37 Fed. Reg. 20510 (1972) (the manual can be obtamed from the FCC). Professor Barrow discusses the procedure for handling fairness complaints and advocates the use of monetary forfeitures in the fairness area. Barrow 469-72.

125. Malone 253. Professor Malone says, "[s]tronger attempts to require broadcasters themselves to produce such programming can lead only to significantly increased federal regulation over programming with the threat of federal dominance of the marketplace of ideas and stultification of first amendment values." Id. It is the purpose of this article to suggest that a good faith efforts standard of enforcing the fiduciary obligation can achieve more controversial programming without resulting in control of the views expressed or in the suppressing of views. 
speak of its activities as "regulation by raised eyebrow."126 Because of the sensitivity of broadcasters to FCC regulation, it would probably not be difficult to make the broadcasters more responsive to their obligations if the FCC were prepared to enforce the obligations by denying license renewals where those obligations are not met. If the FCC were to maintain the distinction between promotion and suppression and enforce the obligations by means of an evaluation of good faith efforts, there would not be any conflict with first amendment values.

This conclusion must be conditional, however. A good faith efforts standard cannot be enforced against the licensees unless the FCC makes a good faith effort to do so..$^{127}$ Furthermore, while a developed doctrine distinguishing between promotion and suppression would make it possible to enforce the standard without suppressimg speech, to achieve that kind of enforceinent, it is necessary to have strong and independent commissioners.

\section{Improvement of the FCC}

Essential to an understanding of the process by which the promotion rather than suppression of speech can be accoinplished is a recognition of the two-tier nature of that process. The primary responsibility rests with the broadcaster, but the FCC inust enforce the

126. Loevinger 291 (where the author refers to the phrase as the "cliche of 'regulation by the lifted eyebrow." "). The inore extensive statement is as follows:

Every broadcasting operation is subject to a host of technical regulations and sooner or later is bound to violate some of them. There may be differences of opinion as to the seriousness and the sanctions of almost any violation, and the attitude of the Commissioners or their staff toward a broadcaster cannot be assuned to be wholly devoid of possible influence toward such issues. Consequently a prudent and responsible broadcaster is likely to be very responsive to the views of FCC commissioners and staff, regardless of his own judgment as to the public needs or demands. Though not often articulated im this context, the fact has become a stereotype of FCC thinking which is reflected in the cliche of 'regulation by the lifted eyebrow:' This siniply indicates recognition of the fact that occasional martyrs or heroes will assert their independence regardless of consequences to themselves; but, in general, people will bend to the will of those who wield power over them, and the independence of individuals and enterprises will be inversely proportional to the power government thus exerts. Id.

127. As former FCC Commissioner Loevinger wrote,

the Commission, like the courts in first amendment cases, must be prepared to accept unpopular, and even hateful or despicable, expression as entitled to constitutional protection and the right to utterance. If the constitutional principles previously declared by the Supreme Court are to be maintained, the Commission cannot, as it has done in the past, declare that "atheists or persons with similar views" are not entitled to radio time, or write a long homily on the virtues of permitting all views regarding religious subjects which concludes by summarily denying the opportunity for atheists or freethmkers to present their views. ... Id. at 293 (citations omitted). 
broadcaster's fiduciary duty and protect the broadcaster who fulfills that duty. In all likelihood the broadcaster will present views on his station that may be "upsetting" and "shocking" to many. ${ }^{128}$ Furthermore, the FCC will, to a large extent, need to modify the accepted role of the licensee in the process. Thus, the FCC will have to be composed of people willing to act vigorously in the public interest with a commitment to the ideals of the first amendment.

Admittedly, the statement that we need better men in the regulatory agencies not only fails to sound novel, but approaches the status of cliché. It has been said before ${ }^{129}$ but the situation seems particularly acute today. ${ }^{130}$ Regulatory commissioners cannot help but be involved with the industry that they regulate, but as Professor William L. Cary poimts out, when appointments are balanced to include pro-industry people there must be soine doubt as to whether the underlying problems in an industry can be tackled. ${ }^{131}$ In addition, what has been called a "subgovernment" has been built up around the regulatory agencies, and through that structure the industry point of view gets communicated vigorously to these agencies. ${ }^{132}$

128. See id. at 294. Loevinger has stated:

With respect to public issues, the primary responsibility of the licensee is not to approve or disapprove the content of material broadcast but to provide facilities for the broadcasting of views that are fairly representative of the range of opinion within the community. If this involves broadcasting views that are upsetting, and even shocking, to many, as it almost surely will in contemporary society, that consequence is the mescapable result of the first amendment mandate as construed by the Court and applied to the linited and licensed broadcasting facilities available in present teclmological and social circumstances. Id.

129. See, e.g., Friendly, A Look at the Federal Administrative Agencies, 60 Colum. L. Rev. 429, 444-46 (1960).

130. Judge Friendly suggests that things have not always been bad, in this context, and points to the high esteem in which the ICC Commissioners were once held. Id. at 431. That situation presented a sharp contrast to the situation in 1960. Id. Whether or not the problem is one of our perception really does not matter. This article is written against a background of coutinuing criticism of the broadcasting industry. Furthermore, the economic structure today appears sufficiently complex so that individuals acting without the support of government can accomplish little. In such a context it seems imperative to attempt to structure regulatory commissions so that such agencies can enforce the public interest in a manner that might get better results than following the concept that what is good for the industry is good for the public.

131. W. Cary, Politics and the Regulatory Agencies 63-64 (1967).

132. Johnson, $A$ New Fidelity to the Regulatory Ideal, 59 GEo. LJ. 869, 883-84 (1971). Cf. E. Griffith, The AMERICan SYstem of Government 102 (4th ed. 1965), where it is said: "The common interest and origin of a conmittee and a bureau, together with the presence in Washington of representatives of the special groups, tend to create the phenomenon of 'government by whirlpools." 'See also id. at 102-03. 
According to FCC Commissioner Nicholas Johnson, the public, as opposed to the industry, is virtually unrepresented before the FCC. ${ }^{133}$ The situation is exascerbated by the fact that many regulatory commissioners feel dependent on the industry that they regulate for their next job. ${ }^{134}$ The situation has becoine so acute that a phrase, the "deferred bribe," has been coined to label the problein. ${ }^{135}$

These difficulties with the regulatory agencies make suggestions such as the one in this article appear futile. Concepts that would work, if adopted in good faith, are subject to the criticisin that they cannot work because of the realities of regulation. Thus, the industries that surround the agencies remain free from suggestions for reform. The suggestion in this article that the FCC could improve broadcasting by enforcing the fiduciary obligation of licensees in a positive way finds substantial roots in the language of the FCC opin-

133. Johnson, supra note 132 , at 884.

134. Id. at 885. Professor Cary stated the problem in the following language: Much has been made of the danger of entertainment by the industry regulated, but the problem is deeper. It rests basically on the question of personal security. Do they want to be liked? Or do they seek power? Do they look for a further career in the administration? And what are they going to do when they leave? Do they plan to work for the industry? If so, some commissioners may feel that they probably should not be too severe in their views, although I found that a company with which I was very strict, though I trust fair, wanted me as its chief executive officer when I left. Another intangible element of personal security is whether a particular commissioner wants to be a judge and therefore may not feel free with counsel who are powerful lobbyists or with their clients who exert a wide influence. Some of the Washington lawyers have developed a remarkably subtle method of exposing the source of their power writhout threatening to exercise it. . . . Cary, supra note 131, at 10-11.

135. See Johnson, supra note 132 , at 885 . Commissioner Johnson indicated that, although the origin of the phrase is unknown, it is often credited to Ralph Nader. Id. at 885 n.68. Commissioner Johnson's description of the process as follows is instructive:

Year after year, regulatory commissioners and staff leave their posts and go to work for the very industries they were supposed to be regulating. The agency is a well-known training ground for industry personnel, a graduate school for the regulatory subgovernment. Many young lawyers, for example, plan to work for the FCC for a few years and then move to higher paying jobs in the commumications bar of Washington. They are naturally careful not to alienate the broadcasters during their stay at the Commission, lest they jeopardize their chances of future employment. Once they are firmly ensconced in private practice, they keep in touch with friends at the Commission, and through them, the Commission pohcies, trends, and views. In part, this phenomenon is a natural result of the communications industries' ability to offer higher salaries to really outstanding staff members. But it is at least equally the result of rather depressing working conditions for yonng staff meinbers, whose creative efforts are often squelched by entrenched section heads and bureau chiefs and by the agency's general lack of will to play a positive regulatory role. At the same time, many of the staff, before coming to the Commission, worked for the very communications industries they now regulate. Id. at 885 .

See also id. at 894-95. 
ions. Yet it departs from the FCC practice because it would involve the FCC in enforcing the good faith efforts of licensees to ineet their admitted obligations. Although the suggestion calls for what might be considered a radically new policy of using positive government controls to promote free speech, it also can be considered very little more than a request that the FCC should live up to its own rhetoric. The FCC must break away froin its present policy of speaking loudly and carrying no stick at all. If the difficulty with the suggestion is that the FCC lacks sufficient vigor or independence to implement it, then the criticism should center on the FCC, not the suggestion.

Although the purpose of this article is to propose the development of an enforceable good faith efforts standard, it is necessary to at least refer to soine suggestions for improving the FCC to the point where the enforcement of such a standard may be a real possibility. Commissioner Johnson proposed that public interest groups, such as Common Cause, could keep lists of recommended commissioners, screen them, and make public their findings, much in the way the organized bar screens judicial appoimtments. ${ }^{136}$ He also suggested salaries comparable with those of the executives in the regulated industry. ${ }^{137}$

Judge Friendly has suggested ten-year terms. ${ }^{138} \mathrm{He}$ also points out that soine have suggested making commissioners who serve the longer term ineligible for reappointment and giving them liberal pensions. ${ }^{139}$ Although he found merit in that suggestion, he thought that it imght be better first to draw on people who retire compulsorily from "universities, industry, labor and government itself."140 Judge Friendly stopped short of recommending life tenure for commissioners, ${ }^{141}$ but he was talking about commissioners of all the federal agencies.

Recently a presidential advisory council recommended that most of the independent regulatory agencies be abolished and their functions taken over by agencies headed by a single administrator. ${ }^{142}$

136. Id. at 896 .

137. Id.

138. Friendly, supra note 129 , at 445 .

139. Id. at $445-46$.

140. Id. at 446.

141. Id. at 445 .

142. The President's advisory Council on Executive Ogranization (Roy L. Ash, Chatrman), a New Regulatory Framework: Report on Selected INDEPENDENT REGULATORY AGENCIES 5-7 (1971). 
The council recognized the unique nature of the FCC by excepting that agency from its recommendations because the FCC "deals with the most sensitive issues in the broadest area since its regulation relates, in part, to program content."143 Since the FCC is involved in the heartland of first amendment values and because, under the more positive regulation discussed in this article, the FCC would become more involved in the protection of free speech, it does not seein excessive to suggest that FCC commissioners be given life tenure subject to a mandatory retirement age and a pension.

Another possibility is to attempt to develop a cadre of independently minded people who would have life tenure as government employees, but would not necessarily be full-time commissioners. One could lengthen the term of commissioners, as Judge Friendly proposes, but then make active use of the former commissioners in other capacities. One possibility that naturally comes to mind is to develop a professional administrative law service in which meinbers have life tenure. Members of that service could principally be administrative law judges, and commissioners could be drawn froin among the ranks of the administrative law judges. After serving a term as a commissioner, they could either revert to the role of administrative law judge or perhaps serve on a policy formulation committee. The possible variations are great and include a service in which the members rotate among commissions. The main point is that their career patterns would not involve going back and forth between government and industry. Furthermore, such a professional service might be able to develop the kinds of ethics and commitinents to the public interest that would enable thein to communicate with the regulated industries and still use their powers to defend the interests of the general public.

In short, we should not admit futility-there are possible solutions. It is not the purpose of this article to present the best solution. What is suggested is that we can find the "good men" to do the job if we want to find thein. ${ }^{144}$ In trying to improve society, we must focus on our institutions, and that includes trymg to structure them in such a way that the men and women who coinprise them can be independent enough to perform their functions in a manner consistent with the expressed goals of their jobs. Our society is long on rhetoric; we must begin to think about how people can live up to that rhetoric.

143. Id. at 116. See also id. at 116-18.

144. See Friendly, supra note 129 , at 444 . 


\section{SUMMARY AND CONCLUSIONS}

Central to the thesis of this article is the problem of how to make the nation's institutions work. Regulation of radio and television rests in the hands of an imdependent regulatory commission subject to review by the courts. If the FCC is going to regulate broadcasting in the public interest, basic doctrines concerning the first amendment must be refined. Furthermore, it is important to begin to develop areas of enterprise in which busmess judgments are made in the public interest. Broadcasting is "in theory" such an area. But discretion cannot be regulated by words alone. The time has coine to develop doctrines that permit the enforcement of obligations imposed upon people performing public functions within the context of corporate organizations.

Broadcasters perform significant public functions in coimection with their control of radio and television. These functions are subject to a fiduciary duty on behalf of the public to present important controversial public issues fairly. It is the thesis of this article that the FCC can and should enforce that obligation by reviewing the performance of broadcast licensees to see that they have made good faith efforts to inform the public in accordance with this obligation. The function of controlling a broadcasting station is too important to be left to the dictates of the profit motive alone. A licensee unust be considered to be $\mathrm{m}$ the business of informing the public as well as in the business of making money through the sale of advertising space. The licensee should perform editorial and educational functions leading to the maximum use of the broadcast media to inform the public. ${ }^{145}$ In this author's opinion, the broadcaster can inform the public by means of entertainment programming as well as through the more traditional news and public affairs programming. ${ }^{146}$ It must be recognized that a licensee must perform a professional function ${ }^{147}$ that includes organizimg not only news and public affairs programming, but also seeking out entertainment programming that deals with controversial issues of public importance.

145. See Comment, The Broadcast Industry: The Commercial Television Licensee and the Editorial Function, 18 WAYNE ST. L. Rev. 683, 704-05 (1972).

146. Cf. Malone 204-05.

147. Cf. Bagdikian, Right of Access: A Modest Proposal, 8 Colum. JouRNALISM REv. 10 (1969). "One function of news is the professional judgment of what is more and what is less important at any given hour. There can be only one lead, one second lead, one third lead. Despite all the flaws in these decisions, someone has to do it, and judges and legislators are not able to do it better." Id. at 12-13. 
The present writer is not in a position to suggest the extent to which a licensee should be forced to actually engage in the production of programming. There should probably be some production requirement in the area of local news and local affairs, but it is also likely that programs dealing with national issues as well as general public issues might better be produced for national consumption. The theory is that if licensees were put in a position of having to demand such programs, then networks and production and distribution companies would market thein. In any event, the function of the licensee involves editorial judgment and judgments of taste as well as business judgments. A licensee is accountable for his business judgments to himself and others who provide the capital, but he must also be held accountable by the FCC for those judgments made as a fiduciary on behalf of the public. ${ }^{148}$

What is important in our society is the development of institutions that function in the public interest. To some extent the profit notive may be a good regulator, but experience in radio and television indicates some of its drawbacks. Where the profit motive proves less than sufficient, the response in this country has been regulation in the public interest. To make that regulation work we must recognize that the discretionary types of duties involved can and must be enforced. The good-faith-efforts concept of regulating the broadcast licensee in the performance of his fiduciary duty to the public, which is discussed in the body of this article, provides a feasible basis for regulating the licensee. We must get away from the idea that the need for discretion is just a license to fail to fulfill a duty and begin to move toward the enforcement of the duties that people operating the radio and television stations owe to the public.

Admittedly, the enforcement of such a duty involves the FCC in the area of first amendment protection. But the fact that free speech is involved can be viewed as an additional reason to insure that licensees perform in the public interest. While it is both true and unfortunate that government does tend to suppress speech, that

148. It should be stressed that to hold a licensee accountable for the exercise of a duty to give fair coverage to controversial issues is very different from encouraging a licensee to limit network programming that criticizes the government. Of course, an agency engaged in regulation of broadcasting could encourage licensees to limit criticism of the government if it chose to abuse its power and neglect the distinction made in this article between promotion and suppression of free speech. That is why it is necessary to deal here with the necessity of improving the FCC. But the fact that some government officials may act to engender the fear of censorship should not be allowed to obscure suggestions designed to promote speech and to insure the full coverage of all viewpoints, including those critical of government. 
should not be considered a reason to permit private persons who control a public resource, the commercial broadcast spectrum, to do so also. In the first place, as discussed in the body of this article, there is a distinction between promotion and suppression that is both recognizable and enforceable. In the second place, our free speech has always depended on the extent of enforceinent by one branch of government-the courts. The crucial question is not whether there is to be a government agency enforcing the promotion of speech, but rather whether that government agency will have sufficient independence and vigor to do so. It is doubtful that the FCC as presently constituted and appointed has that much vigor and imdependence. But instead of using the FCC's present inadequacy as an excuse to avoid improvenent of the broadcast media, it seems far more sensible to improve the FCC. For this reason, some suggestions to that end are presented in the body of this article. The challenge is to develop an agency that possesses that type of independence we tend to attribute to the courts in nost discussions of the protection of first amendment rights. At the same time, the type of regulation involved requires that the FCC also possess the characteristics of an independent regulatory agency, but with more of the vigor associated with our ideal of such a body. The fact that the challenge may be formidable only reflects the difficulties inherent in operating a coinplex society and in attempting to develop institutions that will nove the society toward the achievement of its stated goals.

Inherent in both the regulation of discretion and the promotion of speech is a recognition that discretion and judgment on the part of the licensee is involved. The FCC, in the enforcement of the doctrines discussed here, would have to exercise a considerable amount of discretion and judgment of its own while regulating the discretion and judgnient of the licensees. The present author believes that the process can work. Obviously it involves complicated interpersonal relationships. It involves regulation in good faith in a manner associated today much more closely with the ideal than with the practice. But we are at a point now where inuch needs to be done in the improvement of our institutions, and it is necessary to begin to think in terms of the enforcement of duties involving judgment and professional expertise to a greater extent than we have in the past.

Professor Jaffe warns against overemphasizing the importance of broadcasting in the political sector. ${ }^{149}$ But he is not suggesting

149. See Jaffe 770-71. He is speaking primarily about television in the context of suggestions for counteradvertising and direct public access. 
the elimination of the fairness doctrine and even proposes that it should continue to be applied to advertising. ${ }^{150}$ Furthermore, were the broadcast licensee's obligations more vigorously enforced, radio and television might liave more influence on political life in this country. At the same time, others differ froin Professor Jaffe regarding the importance of broadcasting. For example, Professor Barrow has written the following:

The democratic process is undergoing a time of trial. The growing complexity of society, standardization of tastes and attitudes, the centralization of communications, all tend to isolate the individual and to discourage his responsible participation in public affairs. Television has the greatest potential of all communications media to contribute to social and cultural development and to provide a forum in which the individual can be encouraged to participate in the solution of the problems of his time. ${ }^{151}$

Another factor to consider are some of the recent developinents related to the fairness doctrine mvolving direct public access to the broadcasting media. ${ }^{152}$ With the developinent of cable television, the possibility of public access channels is becoming a reality. ${ }^{163}$ While direct public access serves a very useful purpose in suppleinenting professional broadcast coverage of issues, it is hardly a substitute for the performance of the professional obligations of broadcast licensees discussed in this article. Public access cannot provide the kind of sustained coverage and professional journalistic functions that can be provided by a licensee discharging his fiduciary obligations in a good faith manner. ${ }^{154}$

The development of cable television will also probably result in a greater diversity of stations in a given market, especially in view of the fact that cable systems may be required to originate program-

150. Id. at 777. But Jaffe does say that "the logic of applying the fairness doctrine to advertisements should not be expansively exploited." Id. at 779.

151. Barrow, Balanced Program Service, supra note 38, at 664. See Malone 194, 197 n.15. See also Brandywine-Main Line Radio v. FCC, 473 F.2d 16, 42 (D.C. Cir. 1972).

152. For a good summary and discussion, see generally Jaffe 780-92. Sec also 1972's 'Vox Pop' is Access Through Spots, BroadCASTING, July 10, 1972, at 29-30.

153. See Krebs, Storefront TV Studio Opened by Teleprompter to Aid Harlem, N.Y. Times, July 7, 1972, at 51, cols. 3-4; O'Connor, TV: Public Access Fete, N.Y. Times, July 7, 1972, at 51, cols. 3-4. Cf. Note, Concepts of Broadcast Media Under the First Amendment: A Reevaluation and a Proposal, 47 N.Y.U.L. REv. 83, 108 (1972).

154. Cf. Mayo, supra note 12, at 297 (1954). 
ming. ${ }^{155}$ But in this context one must remember that "[d]iversity of ideas, not multiplicity of forums, is the primary objective of the first amendment."156 Furthermore, at this point in the development of cable television, it would be unwise to make any firm assumptions about the type of programming it will originate in its developed years.

Similarly, the development of public broadcasting suggests that government might exercise positive efforts to realize the potential of broadcasting without requiring the same of the nongovernment licensees. While public broadcasting deserves applause and encouragement, it is not a substitute for a commercial broadcasting system that is well run in the public interest. Furthermore, public broadcasting today finds itself severely hampered by difficult problems. ${ }^{157}$

The existence of possible alternatives to commercial broadcasting should not be used as an excuse to permit the commercial broadcasting system to function on a for-profits-mainly basis. Rather, we should view the commercial broadcasting system as the present heart of the broadcast media. Technological advances that increase diversity or permit listeners to pay for programming they want and new institutional devices such as public broadcasting should be welcomed and developed as an important supplement (and perhaps imcentive) to the commercial systern. But positive efforts must be made to ensure that the cominercial broadcasters, while enjoying the profits from the broadcasting busmess, ${ }^{158}$ function in the public interest in their role as trustees of an important communications system held for the use and benefit of the general public.

Fimally, a few words about constitutional doctrine are necessary. The thesis that the FCC can go much further than it has to require broadcasters to cover controversial issues of public importance without infringing on free speech or limiting creative judg-

155. See United States v. Midwest Video Corp., 406 U.S. 649 (1972). Note that cable systems are regulated. See id. See also United States v. Southwestern Cable Co., 392 U.S. 157 (1968).

156. Barron, An Emerging First Amendment Right 498. See Johnson, supra note 38 , at 20 .

157. See Public Broadcasting: Widening Breach on First Principles, BROADCAsting, July 10, 1972, at 35-36; Macy Resigns as Public TV Head, N.Y. Times, Aug. 11, 1972, at 47, cols. 2-4.

158. See Hearings on S. 2004, supra note 49, at 609 (statement of Senator Tydings). The FCC recently reported that in 1971, the first year in which cigarette advertising was banned from broadcast media, television industry revenues ( $\$ 2.75$ billion) were down $2.1 \%$ from 1970 , although in 1970 cigarette advertising accounted for $6 \%$ of the revenues. P \& F RAdio REG. Rep. No. 25-33 (1972). 
ment on the part of licensees receives constitutional support from Red Lion. ${ }^{159}$ Indeed, the concept grows out of Red Lion, and under that decision it would appear to be constitutional. ${ }^{160}$ As already mentioned, that decision is grounded in the existing scarcity of broadcast frequencies and consequent regulation. ${ }^{101}$ The Supreme Court did not reach the issue on which the thesis of this article is based: that there is no abridgment of free speech by government activity that promotes speech. ${ }^{102}$ Even under the scarcity rationale, it can be argued that newspapers are subject to positive duties with regard to speech. ${ }^{103}$ If government promotion does not violate free speech, it would seem to follow that the press could be subjected to the same kinds of duties as the broadcasters. ${ }^{104}$ Furthermore, underlying the thesis of this article is the idea that corporations that perform public functions, although denominated "private," must fulfill their duties to the public, and especially those duties involving important public values expressed in the Constitution. ${ }^{105}$

At this point it would be premature to extend the concept of more positive regulation to the press even though the present author feels that the doctrine can be developed to allow the enforcement of the public's right to fair coverage of issues without limiting or imfringing free speech. The broadcast media are presently regulated, and as emphasized, the success of the ideas discussed here depends on the development of a strong, independent FCC. ${ }^{160}$ Although it may be necessary to have some sort of judicially enforced right of access to the press, ${ }^{107}$ it is beyond the scope of this article to discuss the concepts developed here as applied to the presently unregulated press. Suffice it to say that the idea of positive regulation and promotion of speech is presented here as an idea that can work, but lias not really been tried with the vigor and good faith dedication that it deserves. As with all legal doctrines and ideas, it will develop with application. Until it is developed through application, it would be wiser to limit it to an industry already subject to extensive regulation by an independent regulatory commission.

159. Red Lion Broadcasting Co. v. FCC, 395 U.S. 367 (1969).

160. See id. at 393-94. Cf. Loevinger 290-91. But see Brandywine-Main Line Radio v. FCC, 473 F.2d 16, 71 n.31 (D.C. Cir. 1972) (dissenting opinion, Bazelon, C.J.).

161. See 395 U.S. at 400-01. See notes 65-66 supra and accompanying text.

162. See 395 U.S. at 401 n.28.

163. See Barron, Access to the Press 1666.

164. Cf. Loevinger 296.

165. Cf. Berle, supra note 43, at 953.

166. Cf. Johnson, The Regulatory Ideal, supra note 132, at 893.

167. See Barron, Access to the Press. But see Bagdikian, supra note 147. 
At the same time it is hoped that the idea of enforcing discretion in the regulation of broadcasting will receive consideration by those who deal with regulation in other areas of economic enterprise. The enforcement of discretion as a supplement or limitation on the profit motive in order to achieve the public interest may be applicable in other areas where there may be a neglect of the public interest. In this context it is somewhat distressing to note that the Supreme Court seems to be taking a somewhat expansive notion of what constitutes private activity; ${ }^{168}$ this may well serve to retard the development of the idea of the public responsibility of corporations that becomes necessary as the social and technological organization of our society continues to change.

In conclusion, it is submitted that a strong, independent FCC could enforce the broadcast licensee's obligation to present controversial issues of public importance fairly to a inuch greater extent than is now done without infringing on first amendment values. Indeed, such regulation would promote the ends of the first amendment. The thrust of this article is that such promotion can be accoinplished without suppressing speech, if done by the enforcement of a good-faith-efforts standard by an independent regulatory commission, itself making a good-faith effort to achieve the goal of an informed public, and itself dedicated to free speech as an important end: Such regulation can be undertaken while preserving wide latitude for the broadcast licensee to use professional judgment and discretion in covering important issues in all types of programming. The goal should be the fullest use of the broadcast media, and that requires the enforcement of the public's rights through regulation in the public interest. The doctrines of enforcement discussed here, by reflecting the distinction between promotion and suppression and by recognizing the need for discretion exercised in good faith to promote the given end, would, if enforced in similar good faith, go a long way toward serving the public interest.

168. See Lloyd Corp. v. Tanner, 407 U.S. 551 (1972). Compare id. at 570-86 (dissenting opinion, Marshall, J.). 
